Biogeosciences, 10, 1893-1908, 2013

www.biogeosciences.net/10/1893/2013/

doi:10.5194/bg-10-1893-2013

(C) Author(s) 2013. CC Attribution 3.0 License.

\title{
Contrasting responses of DMS and DMSP to ocean acidification in Arctic waters
}

\author{
S. D. Archer ${ }^{1,2}$, S. A. Kimmance ${ }^{1}$, J. A. Stephens ${ }^{1}$, F. E. Hopkins ${ }^{1}$, R. G. J. Bellerby ${ }^{3,4,5}$, K. G. Schulz ${ }^{6}$, J. Piontek ${ }^{6,7}$, \\ and A. Engel ${ }^{6}$ \\ ${ }^{1}$ Plymouth Marine Laboratory, The Hoe, Plymouth, PL1 3DH, UK \\ ${ }^{2}$ Bigelow Laboratory for Ocean Science, Maine 04575-0475, USA \\ ${ }^{3}$ Norwegian Institute for Water Research, Bergen, Norway \\ ${ }^{4}$ Bjerknes Centre for Climate Research, University of Bergen, Norway \\ ${ }^{5}$ Geophysical Institute, University of Bergen, Bergen, Norway \\ ${ }^{6}$ GEOMAR, Helmholtz Centre for Ocean Research, 24015 Kiel, Germany \\ ${ }^{7}$ Alfred Wegener Institute, 27570 Bremerhaven, Germany
}

Correspondence to: S. D. Archer (sarcher@bigelow.org)

Received: 30 August 2012 - Published in Biogeosciences Discuss.: 18 September 2012

Revised: 13 February 2013 - Accepted: 27 February 2013 - Published: 20 March 2013

\begin{abstract}
Increasing atmospheric $\mathrm{CO}_{2}$ is decreasing ocean $\mathrm{pH}$ most rapidly in colder regions such as the Arctic. As a component of the EPOCA (European Project on Ocean Acidification) pelagic mesocosm experiment off Spitzbergen in 2010, we examined the consequences of decreased $\mathrm{pH}$ and increased $p \mathrm{CO}_{2}$ on the concentrations of dimethylsulphide (DMS). DMS is an important reactant and contributor to aerosol formation and growth in the Arctic troposphere. In the nine mesocosms with initial $\mathrm{pH}_{T} 8.3$ to 7.5 , equivalent to $p \mathrm{CO}_{2}$ of 180 to $1420 \mu$ atm, highly significant but inverse responses to acidity (hydrogen ion concentration $\left[\mathrm{H}^{+}\right]$) occurred following nutrient addition. Compared to ambient $\left[\mathrm{H}^{+}\right]$, average concentrations of DMS during the mid-phase of the $30 \mathrm{~d}$ experiment, when the influence of altered acidity was unambiguous, were reduced by approximately $60 \%$ at the highest $\left[\mathrm{H}^{+}\right]$and by $35 \%$ at $\left[\mathrm{H}^{+}\right]$equivalent to $750 \mu$ atm $p \mathrm{CO}_{2}$, as projected for 2100 . In contrast, concentrations of dimethylsulphoniopropionate (DMSP), the precursor of DMS, were elevated by approximately $50 \%$ at the highest $\left[\mathrm{H}^{+}\right]$and by $30 \%$ at $\left[\mathrm{H}^{+}\right]$corresponding to $750 \mu$ atm $p \mathrm{CO}_{2}$. Measurements of the specific rate of synthesis of DMSP by phytoplankton indicate increased production at high $\left[\mathrm{H}^{+}\right]$, in parallel to rates of inorganic carbon fixation. The elevated DMSP production at high $\left[\mathrm{H}^{+}\right]$was largely a consequence of increased dinoflagellate biomass and in particular, the increased abundance of the species Heterocapsa rotundata. We
\end{abstract}

discuss both phytoplankton and bacterial processes that may explain the reduced ratios of DMS:DMSPt (total dimethylsulphoniopropionate) at higher $\left[\mathrm{H}^{+}\right]$. The experimental design of eight treatment levels provides comparatively robust empirical relationships of DMS and DMSP concentration, DMSP production and dinoflagellate biomass versus $\left[\mathrm{H}^{+}\right]$in Arctic waters.

\section{Introduction}

The surface energy budget of the Arctic is heavily influenced by cloud formation processes (Curry et al., 1996; Sedlar et al., 2011), which correspondingly play an important role in the melting and freezing of the perennial sea ice (Kay and Gettelman, 2009). The dominance in summer of small Aitken-mode aerosol particles has been correlated to concentrations of MSA (methane sulfonic acid) and atmospheric DMS (dimethylsulphide), suggesting a link between the magnitude of DMS emission and cloud albedo over the Arctic (Ferek et al., 1995; Quinn et al., 2002). Although biogenic primary organic aerosols have been proposed as a source of new particles in the Arctic atmosphere (Bigg and Leck, 2008; Orellana et al., 2011), recent direct measurements of particle flux suggest they may make only a minor contribution to aerosol abundance (Held et al., 2011) 
unless proposed mechanisms of particle fragmentation are substantiated (Karl et al., 2012). Further evidence of the potential importance of DMS to Arctic albedo is provided by a chemical transport model with size-resolved aerosol microphysics, which illustrates the substantial contribution of sulphuric acid to formation of CCN (cloud condensation nuclei) during the Arctic summer (Korhonen et al., 2008). DMS influences atmospheric chemistry in other ways including the concentrations of other climate active gases such as ozone, methane, ammonia and isoprene (Toumi, 1994; Johnson and Bell, 2008; Chen and Jang, 2012). Understanding how DMS emissions are likely to alter in the future is therefore especially important in relation to the rapidly changing Arctic climate

The Arctic Ocean is particularly susceptible to ocean acidification driven by increasing atmospheric $p \mathrm{CO}_{2}$ (Steinacher et al., 2009). The present average surface ocean $\mathrm{pH}_{T}$ of 8.2 is $0.1 \mathrm{pH}_{T}$ units lower than in pre-industrial times (Caldeira and Wickett, 2003), representing a $30 \%$ increase in the concentration of hydrogenions $\left[\mathrm{H}^{+}\right]$. The largest $\mathrm{pH}$ changes worldwide are predicted to occur in Arctic surface waters, where $\left[\mathrm{H}^{+}\right]$may increase by $185 \%\left(\Delta \mathrm{pH}_{T}=-0.45\right)$ by 2100 (Steinacher et al., 2009). Undersaturation of aragonite, a mineral phase of $\mathrm{CaCO}_{3}$, is projected to occur locally in Arctic surface waters within a decade (Steinacher et al., 2009). The rapidity and scale of change of acidity and carbonate chemistry of the surface oceans has the potential to alter the physiology of microorganisms and impact on biogeochemical processes (Riebesell and Tortell, 2011); including the production and removal of biogenic trace gases such as DMS.

Evidence that DMS concentrations and hence emissions are likely to alter significantly in response to ocean acidification stem primarily from $\left[\mathrm{H}^{+}\right]$perturbation experiments in natural waters (Wingenter et al., 2007; Vogt et al., 2008; Lee et al., 2009; Hopkins et al., 2010; Kim et al., 2010; Avgoustidi et al., 2012). However, conclusive identification of the mechanisms involved in the altered DMS concentrations is limited, making it difficult to develop predictive models of the effects of ocean acidification on DMS emissions. Understandably, previous mesocosm studies have concentrated on monitoring changes in concentrations of DMS and in some cases DMSP (dimethylsulphoniopropionate), over the duration of experiments in the different treatment. An improved understanding of the mechanisms behind differences in DMS or DMSP concentrations requires a greater emphasis on measuring the rates of the most relevant processes.

DMS is a product of the enzymatic cleavage of the osmolyte, $\beta$-dimethylsulphoniopropionate, synthesised by a variety of phytoplankton (Reed, 1983; Keller et al., 1989). Phytoplankton DMSP is transformed to the dissolved phase through active exudation, cell autolysis during senescence, viral lysis, and grazing by zooplankton (Stefels et al., 2007). Once in the dissolved phase, pelagic bacteria generally either cleave DMSP generating DMS, or demethylate/demethiolate
DMSP to methyl-mercaptopropionate, methanethiol or inorganic sulphur (Kiene et al., 2000). In addition, bacterial consumption competes with photochemical transformation as the major loss process for DMS (Vila-Costa et al., 2008; del Valle et al., 2009).

A number of processes impacted by ocean acidification are likely to alter the balance between production and removal of DMS in the surface ocean. If ocean acidification results in changes in phytoplankton primary production (Rost et al., 2008; Riebesell and Tortell, 2011), then total DMSP production may be altered as a consequence. Intracellular concentrations of DMSP are highly variable between phytoplankton taxa (Keller et al., 1989). As a result, changes in primary production may have a considerably larger influence on DMSP production if they involve alterations in the biomass of the principle DMSP producing taxa or are accompanied by changes in the proportion of the phytoplankton community that comprises DMSP-producing taxa. Recent laboratory-based studies found contrasting responses in intracellular DMSP accumulation amongst three phytoplankton taxa exposed to varied levels of $p \mathrm{CO}_{2}$ (Spielmeyer and Pohnert, 2012), possibly reflecting the variety of physiological functions attributed to DMSP (Nishiguchi and Somero, 1992; Stefels, 2000; Sunda et al., 2002). A complex network of enzymatic processes largely dictate DMS concentrations in surface waters (Carpenter et al., 2012) some of which may be prone to alteration in activity in the face of changing $\left[\mathrm{H}^{+}\right]$. Bacterial ectoenzyme activities have been shown to be particularly sensitive to changes in $\left[\mathrm{H}^{+}\right]$(Piontek et al., 2010), with potential consequences for the bacterial catabolism of DMSP and removal of DMS. Furthermore, uncharacterised algal DMSP lyases, some of which may be extracellular, also show a variety of $\left[\mathrm{H}^{+}\right]$optima between species and strains in in vitro assays (Steinke et al., 1998) and may alter activity in relation to changes in environmental $\left[\mathrm{H}^{+}\right]$.

In light of the pressing need to predict how increasing levels of atmospheric $\mathrm{CO}_{2}$ are going to alter the functioning of the Arctic Ocean ecosystem, we participated in a major mesocosm experiment within the framework of the European Project on Ocean Acidification (EPOCA). The study differs in several respects from previous experiments that have examined the influence of altered $p \mathrm{CO}_{2}$ and $\mathrm{H}^{+}$on DMS concentrations in mesocosm experiments. Firstly, In addition to monitoring how DMS and DMSP concentrations vary, we addressed two key factors that potentially alter DMS concentrations at different levels of acidity: (i) direct measures of DMSP synthesis rates by phytoplankton; and (ii) determination of which components of the phytoplankton communities contribute to the variations in DMSP production. Secondly, this was the first experiment of this type to use natural Arctic microbial communities. Moreover, the larger enclosed volumes and floating structures mimicked the in situ environment more closely than previously used fixed structures containing smaller volumes of seawater. Thirdly, the experimental design of a series of mesocosms of increasing 
acidity that mimicked conditions predicted under increasing atmospheric $p \mathrm{CO}_{2}$ allowed us to establish functional relationships relevant to the development of predictive models of DMS emission.

\section{Materials and methods}

\subsection{Location and experimental design}

The experiment took place in Arctic waters in Kongsfjorden $\left(78^{\circ} 56.2^{\prime} \mathrm{N}, 11^{\circ} 53.6^{\prime} \mathrm{E}\right)$ or $\left(78^{\circ} 56^{\prime} 12^{\prime \prime \prime} \mathrm{N}, 11^{\circ} 53^{\prime} 36^{\prime \prime} \mathrm{E}\right)$, on the west coast of Spitzbergen, in the Svalbard Archipelago, during early-mid summer from 31 May (t-7) to 7 July 2010 (t30). Nine large, floating, cylindrical mesocosms approximately $2 \mathrm{~m}$ in diameter and $17 \mathrm{~m}$ deep and containing approximately $50 \mathrm{~m}^{3}$, were moored in the fjord within $\sim 100 \mathrm{~m}$ of each other offshore from the settlement of NyÅlesund. The mesocosm bags were constructed of thermoplastic polyurethane (TPU) and capped, but not sealed, by a polyvinyl chloride (PVC) cover. Both the TPU and PVC transmitted $\sim 95 \%$ of the incoming photosynthetically active radiation (PAR). The mesocosms were filled with fjord water screened through $3 \mathrm{~mm}$ mesh to eliminate larger organisms. To ensure consistency in the interpretation of results the 7 June was designated as t0. On 2 June (t-5) the mesocosms were closed, allowing no further exchange with the surrounding fjord water.

To alter the dissolved inorganic carbon concentration whilst maintaining constant alkalinity, $\mathrm{CO}_{2}$-saturated seawater was added to seven of the mesocosms (Schulz et al., 2013). A $1.5 \mathrm{~m}^{3}$ volume of seawater filtered through a $50 \mu \mathrm{m}$ mesh was saturated with high purity $\mathrm{CO}_{2}$ and varied quantities were mixed through the depth of each mesocosm over a period of 5 days (t-1 to t4). The two control mesocosms received no $\mathrm{CO}_{2}$ addition, and maintained the initial ambient conditions of the fjord (175-180 $\mu \mathrm{atm})$ throughout the experiment. This resulted in a gradient of $p \mathrm{CO}_{2}$ levels from $\sim 185$ to $1420 \mu$ atm between the nine mesocosm bags.

Nitrate, phosphate and silicate were added to all the mesocosms early on t13 in order to stimulate phytoplankton growth. The addition of nutrients to all mesocosms ensured that differences between mesocosms were driven primarily by variations in $\mathrm{pH}$ and $p \mathrm{CO}_{2}$ rather than nutrient availability, while non-limiting nutrient conditions existed. Full details of the experimental set-up, evolution of the carbonate systems in the mesocosms and nutrient additions are given in this issue by Riebesell et al. (2013), Bellerby et al. (2013) and Schulz et al. (2013), respectively.

\subsection{Quantification of DMS and DMSP concentrations}

Water was sampled from each mesocosm using a depthintegrating water sampler (IWS) (Hydrobios, Kiel, Germany). The sampler was programmed to collect a $12 \mathrm{~m}$ integrated sample as it was gradually raised through the water column. Samples were generally obtained from all mesocosms between 09:00 and 10:30 LT (local time). Glassstoppered bottles were gently filled from the sampler in order to avoid air-contact and bubbling. Samples were transported in a dark cool box back to the laboratory onshore and all were analysed within $2 \frac{1}{2} \mathrm{~h}$ of collection. For DMS concentrations, $4 \mathrm{~mL}$ samples were gently filtered through a $25 \mathrm{~mm} \mathrm{GF/F}$ (glass fiber) filter and transferred to a purge tower, avoiding any contact with air, and immediately analysed. For total DMSP (DMSPt) concentrations, which includes particulate DMSP (DMSPp) and a minor fraction that comprises dissolved DMSP (DMSPd), $7 \mathrm{~mL}$ water samples were fixed using $35 \mu \mathrm{L}$ of $50 \% \mathrm{H}_{2} \mathrm{SO}_{4}$ (Kiene and Slezak, 2006). On return to Plymouth Marine Laboratory, UK, the $7.035 \mathrm{~mL}$ samples were hydrolysed for $>6 \mathrm{~h}$ with a pellet of $\mathrm{NaOH}$ to convert DMSP to DMS. One $\mathrm{mL}$ of the samples was then carefully transferred to a glass purge tower for extraction of DMS. DMS concentrations were measured using a purge system and cryogenic trap linked to a Varian 3800 gas chromatograph equipped with a pulsed flame photometric detector (PFPD). When triplicate experimental samples were used to test for analytical error, standard deviation was typically $<10 \%$ and $<10 \%$ of the mean for DMS and DM$\mathrm{SPt}$, respectively. DMS standards for calibration were prepared from DMSP (> $98 \%$ purity; Centrum voor Analyse, Spectroscopie and Synthese, Rijksuniversiteit Groningen) in a $1.0 \mathrm{~mol} \mathrm{~L}^{-1} \mathrm{NaOH}$ solution in Milli-Q water. An eightpoint calibration was carried out every second day throughout the experiment, with an $r^{2}$ for the resulting linear regression of ng sulphur versus square root of the peak area of typically $>0.995$.

\subsection{DMSP synthesis and production rates}

On each experimental date, $20 \mathrm{~L}$ of water from approximately $6 \mathrm{~m}$ depth was collected in $2 \times 1 \mathrm{~L}$ acid-cleaned carboys from each of three mesocosms that spanned the range of $p \mathrm{CO}_{2}$ concentrations. Trace amounts of $\mathrm{NaH}^{13} \mathrm{CO}_{3}$, equivalent to $\sim 6 \%$ of in situ dissolved inorganic carbon (DIC), were added to each $10 \mathrm{~L}$ volume and following gentle mixing, this was then used to fill $12 \times 1.25 \mathrm{~L}$ acid-cleaned polycarbonate incubation bottles for each mesocosm or " $p \mathrm{CO}_{2}$ treatment". The addition of $\mathrm{NaH}^{13} \mathrm{CO}_{3}$ is estimated to have altered $\left[\mathrm{H}^{+}\right]$by $<3 \%$ in the incubated water; within the range of daily variations in individual mesocosms

The bottles were incubated at approximately $1 \mathrm{~m}$ depth, close to the pier at Ny-Ålesund. Photosynthetically active radiation (PAR) at the depth of the incubations averaged $53 \%$ (range 23 to $85 \%$ ) of the surface irradiance on the 8 experimental dates and was equivalent to an average depth of $2.3 \mathrm{~m}$ (range 0.5 and $9 \mathrm{~m}$ ) in the mesocosm bags. The 12 bottles provided 4 incubation time points in triplicate for each treatment. At each time point, $1 \mathrm{~L}$ was gravity filtered in the dark onto a $47 \mathrm{~mm} \mathrm{GF/F} \mathrm{filter.} \mathrm{Filters} \mathrm{were} \mathrm{placed} \mathrm{in} 20 \mathrm{~mL}$ 
crimp-cap vials with $10 \mathrm{~mL}$ of $0.5 \mathrm{M} \mathrm{NaOH}$. For storage, samples were frozen at $-20^{\circ} \mathrm{C}$.

Determination of de novo DMSP synthesis rates ( $\mu \mathrm{DMSP}$ ) was carried out according to Stefels et al. (2009). Incorporation of ${ }^{13} \mathrm{C}$ into DMSP was determined by proton transfer reaction mass spectrometry (PTR-MS) of DMS swept from the $20 \mathrm{~mL}$ vials and recorded as mass 63,64 and 65 of protonated forms of ${ }^{12} \mathrm{C}$-DMS, ${ }^{13} \mathrm{C}$-DMS ${ }^{34} \mathrm{~S}$-DMS, respectively. The masses from 30 data points, at a $1 \mathrm{~s}$ dwell interval, of the peak of the DMS signal were used to calculate the mass ratio of $1 \times{ }^{13} \mathrm{C}$-DMSP $\left({ }^{64} \mathrm{MP}\right)$ at each point. A weighted average approach that gives most weight to the initial points of the exponentially decreasing DMS peak was used to calculate the mass ratio ${ }^{64} \mathrm{MP}_{t}$ for each sample at each time point. The mass ratio progress method described by Stefels et al. (2009) was applied to calculate $\mu$ DMSP. This applied information from culture-based studies of Emiliania huxleyi to calculate the isotope fractionation factor (Stefels et al., 2009). The exact tracer addition was calculated from the weight of $\mathrm{NaH}^{13} \mathrm{CO}_{3}$ added and the daily measurements of DIC in the mesocosms. By incorporating shorter time intervals of $\sim 8 \mathrm{~h}$ within the $\sim 24 \mathrm{~h}$ incubations, uncertainty associated with turnover of the DMSP pool is reduced, ensuring $\mu \mathrm{DMSP}$ measurements represent close to gross synthesis rates.

\subsection{Inorganic carbon fixation rates}

Primary production was determined from the incorporation of ${ }^{14} \mathrm{C}$ into particulate and dissolved organic matter as described in Engel et al. (2013). Water samples from the mesocosms were obtained at the same times and integrated depth as those used for the determination of DMS and DMSP concentrations and for the incubations for DMSP synthesis. The polycarbonate bottles used for ${ }^{14} \mathrm{C}$-incorporation were incubated at $1 \mathrm{~m}$ depth in the vicinity of the mesocosms.

\subsection{Variable fluorescence measurements}

A fluorescence induction and relaxation (FIRe) fluorometer (Satlantic Inc., Halifax, Nova Scotia, Canada) was used to acquire discrete measurements in dark-adapted samples. Excitation was provided by a high luminosity, blue and green light emitting diode (LED) array (450 and $500 \mathrm{~nm}$ peak heights). Filtered $(0.2 \mu \mathrm{m})$ sample controls (blanks) were analysed at the gain chosen for the measurement on the sample and subtracted from the sample fluorescence sequence at the time of fitting the KPF physiological model. Cell-free controls showed no soluble fluorescence. A detailed description of the protocol used is provided in Ragni et al. (2008). The retrieved parameter used in the present study is the maximum potential quantum efficiency of photosystem II $\left(F_{\mathrm{v}} / F_{\mathrm{m}}\right) . F_{\mathrm{v}} / F_{\mathrm{m}}$ was calculated from triplicate measures of $F_{\mathrm{o}}$ and $F_{\mathrm{m}}$ in each mesocosm on each day and included propagation of the uncertainty in each parameter.

\subsection{Bacterial production rates}

Bacterial protein production was estimated from the uptake of ${ }^{14} \mathrm{C}$-leucine that was added to depth-integrated samples from the mesocosms at $40 \mathrm{nmol} \mathrm{L}^{-1}$ final concentration. Incubations were terminated by the addition of trichloroacetic acid (TCA) at a final concentration of $5 \%$ and processed by the microcentrifuge method. Briefly, samples were centrifuged at $14000 \times g$ to gain a cell pellet that was washed twice with $5 \%$ TCA. Incorporation into the TCA-insoluble fraction was measured by liquid scintillation counting after suspension of the cell pellet in scintillation cocktail (Piontek et al., 2013).

\subsection{Flow cytometry and group-specific DMSP cell content}

Phytoplankton composition and abundance were determined by analysis of fresh samples on a Becton Dickinson FACSort flow cytometer equipped with a $15 \mathrm{~mW}$ laser exciting at $488 \mathrm{~nm}$ and with a standard filter set-up. Samples were analysed at high flow rate $\left(\sim 70 \mu \mathrm{L} \mathrm{min}^{-1}\right)$, and specific phytoplankton groups were discriminated in bivariate scatter plots by differences in side scatter and red-orange fluorescence (Tarran et al., 2001).

In order to identify the phytoplankton responsible for DMSP production in the mesocosms, fluorescence activated cell sorting was used to determine group-specific intracellular DMSP content (Archer et al., 2011). This was carried out using water sampled from two contrasting mesocosms on two separate occasions towards the end of the experiment (t18 and $\mathrm{t} 21$ ). The same water samples were also size-fractionated using a membrane filter to separate the $<20$ and $>20 \mu \mathrm{m}$ size particles. DMSP concentration was measured in the filtrate and the $>20$ DMSP portion calculated by difference.

\subsection{Statistical analyses}

Model 1 linear regression was used to determine the response of DMS and DMSPt concentrations to increased acidity over distinct phases of the mesocosm experiments. For each of the three phases of the experiment, daily measurements of DMS and DMSP in each mesocosm were used as the dependent variables against the independent variable consisting of the mean $\left[\mathrm{H}^{+}\right]$in the mesocosm during that phase. The significance of the linear regression was determined by ANOVA (analysis of variance). Linear regression analysis was also used to explore the relationship between phytoplankton composition and DMSP concentrations and between bacterial production and DMS:DMSP ratios. In the latter case the possibility that autocorrelation, associated with time series data of this type, may have led to an overestimate of the significance of the relationships was tested using the Durbin-Watson statistic. In the present study, hydrogen ion 
equivalent concentration $\left[\mathrm{H}^{+}\right]$is used as the basis to examine the response to ocean acidification, providing a linear scale against which to compare other parameters, as opposed to $\mathrm{pH}$. Alterations in extracellular $\left[\mathrm{H}^{+}\right]$may impact a greater proportion of physiological processes in heterotrophic and autotrophic microbes than changes in $\mathrm{CO}_{2}$ availability per se (Raven, 2011). However, $\left[\mathrm{H}^{+}\right]$and $p \mathrm{CO}_{2}$ are directly related in the context of the present study.

\section{Results}

Water initially enclosed within the mesocosms was characteristic of a post-spring bloom environment. In particular, inorganic macronutrient concentrations were diminished $\left(0.12 \mu \mathrm{mol} \mathrm{L}^{-1} \mathrm{NO}_{3}, 0.7 \mu \mathrm{mol} \mathrm{L}^{-1} \mathrm{NH}_{4}, 0.13 \mu \mathrm{mo} \mathrm{L}^{-1}\right.$ $\mathrm{PO}_{4}$ and $0.25 \mu \mathrm{mol} \mathrm{L}{ }^{-1} \mathrm{Si}$ ) (Schulz et al., 2013), chlorophyll $a$ concentrations were low $\left(0.21 \mu \mathrm{g} \mathrm{L}^{-1}\right)$ and the $p \mathrm{CO}_{2}$ concentration had been reduced to $170 \mu \mathrm{atm}$, equivalent to a $\mathrm{pH}_{T}$ of 8.3 (Bellerby et al., 2013). Correspondingly, DMSP concentrations were low $\left(10 \pm 2 \mathrm{nmol} \mathrm{L}^{-1}\right)$ whilst initial DMS concentrations were relatively high $\left(1.5 \pm 0.1 \mathrm{nmol} \mathrm{L}^{1}\right)$; equivalent to a $15 \%$ DMS:DMSP molar ratio. Water temperature gradually increased from an initial $2.0^{\circ} \mathrm{C}$ to a maximum of $5.5^{\circ} \mathrm{C}$ towards the end of the experiment (Fig. 1). Despite the almost constant daylight, daily average and maximum levels of photosynthetically active radiation (PAR) at the surface varied almost 3 -fold but with no clear trend other than a sustained period of lower irradiance at the end of the experiment (Fig. 1). The addition of nutrients on the morning of $\mathrm{t} 13$ boosted concentrations to $5.6 \mu \mathrm{mol} \mathrm{L}{ }^{-1} \mathrm{NO}_{3}, 0.40 \mu \mathrm{mol} \mathrm{L}{ }^{-1} \mathrm{PO}_{4}$ and between 1.31 and $1.59 \mu \mathrm{mol} \mathrm{L}^{-1} \mathrm{Si}$. These concentrations rapidly declined to reach levels as low as the initial conditions by $\mathrm{t} 28$.

As environmental conditions changed during the experiment, the extent to which the different levels of acidity in the mesocosms influenced biological processes is likely to have been altered. Phytoplankton biomass (chlorophyll $a$ ) in the mesocosms peaked on three occasions between $t 4$ and t28 (Fig. 1). This pattern defined three distinct phases of the experiment (Schulz et al., 2013). In an initial "post-bloom" phase (PI) from t4 to t12, chlorophyll $a$ reached between 1.0 and $1.5 \mu \mathrm{g} \mathrm{L}^{-1}$ amongst the mesocosms, phytoplankton biomass appeared to be dominated by nanophytoplankton that varied in maximum abundance from 1700 to 5800 cells $\mathrm{mL}^{-1}$ and primary production was partially constrained by rates of nutrient remineralisation. A second phase (PII) from $\mathrm{t} 13$ to $\mathrm{t} 21$ was initiated by the addition of nutrients to nonlimiting concentrations that stimulated phytoplankton production; in particular, picoeukaryote populations increased to maximum abundances of 44 to $143 \times 10^{3}$ cells $\mathrm{mL}^{-1}$ between the mesocosms. During PII, chlorophyll $a$ reached maximum values of between 0.7 and $2.1 \mu \mathrm{g} \mathrm{L}^{-1}$ amongst the mesocosms. As primary productivity was unconstrained by nutrient availability during PII it may be argued that
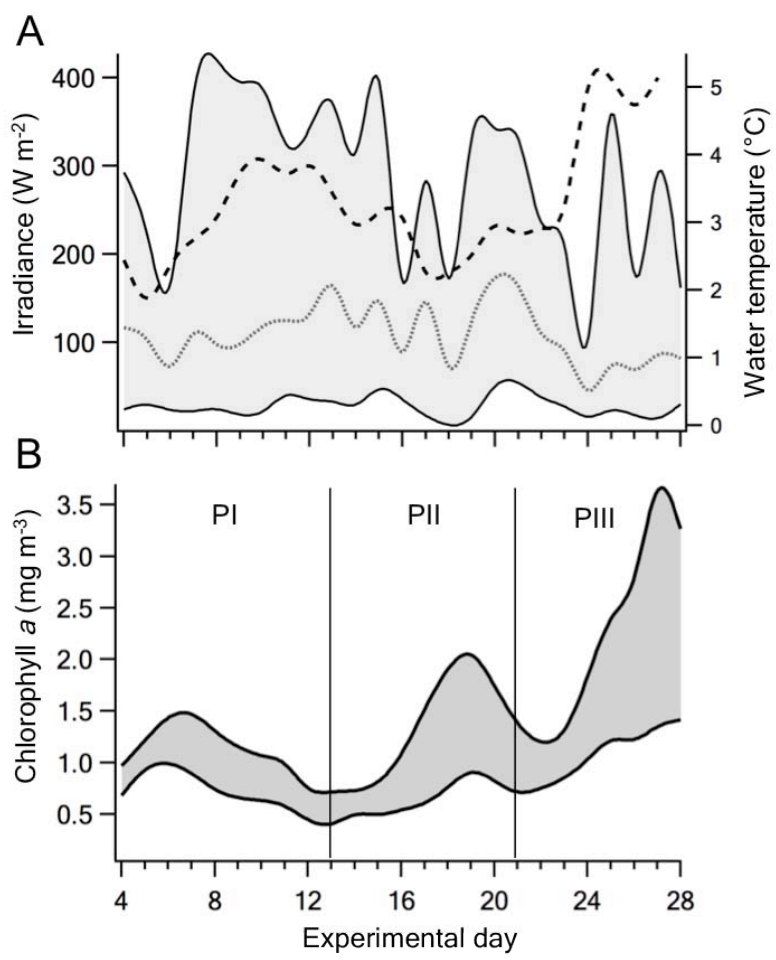

Fig. 1. Temporal change in environmental variables: (A) surface irradiance (PAR 400-750 nm) and water temperature during the mesocosm experiment. The shaded area spans the range of minimum and maximum irradiance on each day and the dotted grey line represents the daily average value. The dashed line is the average water temperature in the mesocosm bags. (B) The grey shaded area spans the range of chlorophyll $a$ concentrations measured in the nine mesocosms on each day. The vertical lines show the assigned phases (PI to PIII); nutrient addition occurred on t13.

the differences between mesocosms were likely to be principally driven by the varied levels of acidity. Rapidly decreasing inorganic nutrient concentrations and the demise of the picoeukaryote populations marked the start of the third phase (PIII), from t22 to t28; during which diatom and dinoflagellate populations became increasingly dominant and the largest divergence in phytoplankton biomass occurred amongst the mesocosms. During PIII differences between mesocosms possibly reflected a complex combination of nutrient availability, acidity and community succession inherited from PII.

\subsection{Patterns of DMS and DMSP temporal progression}

To facilitate interpretation of the data and in common with other studies in this issue, the nine mesocosms can be classified into three groups of low, medium and high acidity. Linked broadly to the build-up of chlorophyll $a$, DMSPt concentrations increased during the experiment in all mesocosms, with varied patterns evident in low, medium and particularly high acidity treatments (Fig. 2a). The patterns of 
Table 1. Significance of the linear regressions between DMSPt concentration $\left(\mathrm{nmol} \mathrm{L}^{-1}\right)$ and $\left[\mathrm{H}^{+}\right]\left(\times 10^{-8} \mathrm{Eq} \mathrm{L}^{-1}\right)$ and between DMS concentration $\left(\mathrm{nmol} \mathrm{L}{ }^{-1}\right)$ and $\left[\mathrm{H}^{+}\right]\left(\times 10^{-8} \mathrm{EqL}^{-1}\right)$ during each phase of the experiment. Where $a$ is the coefficient $( \pm \mathrm{SE})$ of the slope and $b$ is the intercept $( \pm \mathrm{SE}), P$ is the significance of the $F$ value of the ANOVA of the regression, $n$ is the number of observations and $\mathrm{n} / \mathrm{s}$ is not significant at $P<0.05$.

\begin{tabular}{lrrr}
\hline Variable & Phase I & Phase II & Phase III \\
\hline DMSPt & & & \\
\hline$a$ & $\mathrm{n} / \mathrm{s}$ & $9.82 \pm 1.98$ & $9.32 \pm 2.95$ \\
$b$ & $29.9 \pm 1.5$ & $32.9 \pm 2.6$ & $48.4 \pm 3.4$ \\
$P$ & $(0.077)$ & $\left(3.9 \times 10^{-6}\right)$ & $(0.0024)$ \\
$n$ & $(67)$ & $(80)$ & $(61)$ \\
\hline DMS & \multicolumn{3}{|}{} \\
\hline$a$ & $\mathrm{n} / \mathrm{s}$ & $-2.2 \pm 0.3$ & $2.3 \pm 0.6$ \\
$b$ & $2.5 \pm 0.2$ & $8.4 \pm 0.3$ & $3.9 \pm 0.9$ \\
$P$ & $(0.083)$ & $\left(1.9 \times 10^{-13}\right)$ & $(0.0002)$ \\
$n$ & $(72)$ & $(81)$ & $(63)$ \\
\hline
\end{tabular}

DMS concentration varied both between levels of acidity and from the patterns of DMSPt progression, particularly amongst the mesocosms of low and medium acidity (Fig. 2b). The peak in DMS concentrations in medium and low acidity treatments during PII and subsequent decline during PIII, contrasts with the gradually accumulating DMSPt. Amongst the high acidity mesocosms, the peaks in DMSPt concentrations during PII were not matched by elevated DMS concentrations, which did not reach maximum values until PIII.

Differences in the response of DMSP and DMS concentration to levels of $\left[\mathrm{H}^{+}\right]$occurred between the three phases of the experiment (Fig. 3). Although values of DMS and DMSPt averaged over the duration of PI appeared to decrease at high $\left[\mathrm{H}^{+}\right]$, when the full dataset of daily measurements was used in a linear regression analysis this did not amount to a significant decrease of either DMS or DMSPt (Table 1). During PII, DMS and DMSPt show contrasting and highly significant responses to $\left[\mathrm{H}^{+}\right]$(Fig. 3; Table 1). Compared to ambient $\left[\mathrm{H}^{+}\right]$, average concentrations of DMS during PII were reduced by approximately $60 \%$ at the highest $\left[\mathrm{H}^{+}\right]$and by $35 \%$ at $\left[\mathrm{H}^{+}\right]=1.67 \times 10^{-8} \mathrm{Eq} \mathrm{L}^{-1}$; equivalent to $750 \mu \mathrm{atm} p \mathrm{CO}_{2}$. In contrast, DMSPt concentrations were elevated by approximately $50 \%$ at the highest $\left[\mathrm{H}^{+}\right]$ and by $30 \%$ at $\left[\mathrm{H}^{+}\right]=1.67 \times 10^{-8} \mathrm{EqL} \mathrm{L}^{-1}$; corresponding to $750 \mu$ atm $p \mathrm{CO}_{2}$. During PIII daily measurements of DMS and DMSPt concentrations were again significantly related to $\left[\mathrm{H}^{+}\right]$but to a lower degree than during PII (Fig. 3; Table 1). Both DMS and DMSPt concentrations were elevated with increased $\left[\mathrm{H}^{+}\right]$concentration during PIII. However, particularly in the case of DMS, the high values in mesocosm 9 , at the highest $\left[\mathrm{H}^{+}\right]$concentration, had a disproportionate influence on the significance of the linear regression (Fig. 3).
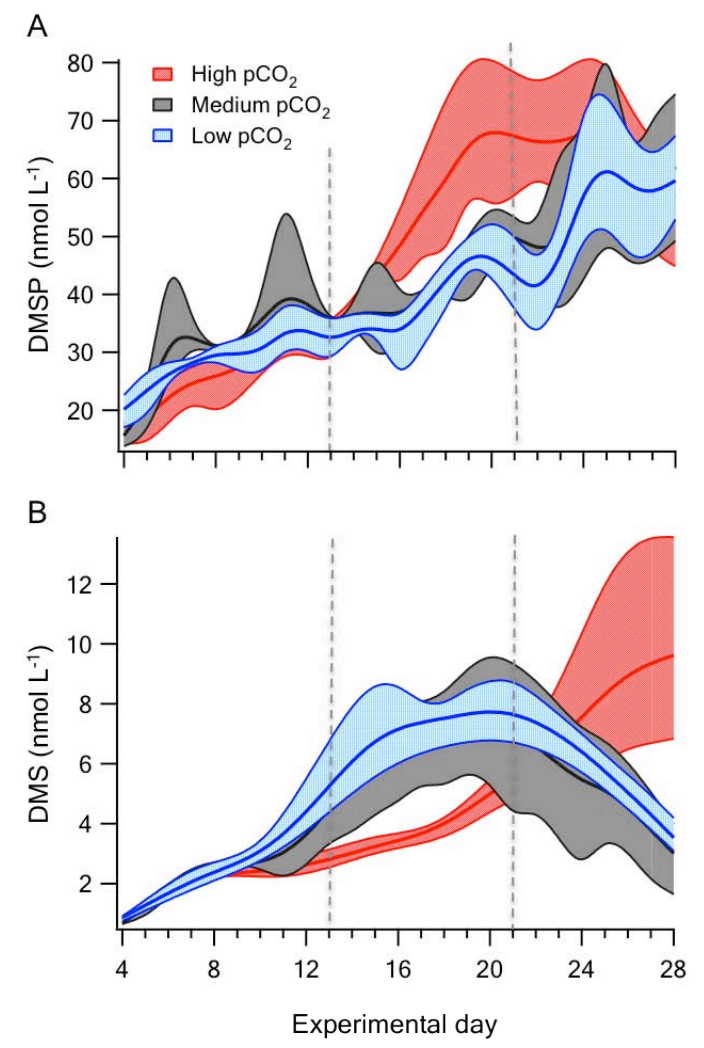

Fig. 2. Temporal progression of (A) DMSPt concentration and (B) DMS concentration in the three Low $p \mathrm{CO}_{2}$ mesocosms (initial $\left[\mathrm{H}^{+}\right]$: 0.5 to $0.7 \times 10^{-8} \mathrm{EqL}^{-1}$; initial $p \mathrm{CO}_{2}: 185$ to $270 \mu \mathrm{mol} \mathrm{kg}^{-1}$ ), three Medium $p \mathrm{CO}_{2}$ mesocosms (initial $\left[\mathrm{H}^{+}\right]$: 0.9 to $1.5 \times 10^{-8} \mathrm{Eq} \mathrm{L}^{-1} ; p \mathrm{CO}_{2}: 375$ to $\left.685 \mu \mathrm{mol} \mathrm{kg}{ }^{-1}\right)$ and three High $p \mathrm{CO}_{2}$ mesocosms (initial $\left[\mathrm{H}^{+}\right]$: 1.8 to $3.1 \times 10^{-8} \mathrm{Eq} \mathrm{L}^{-1}$; $p \mathrm{CO}_{2}: 820$ to $1420 \mu \mathrm{mol} \mathrm{kg}{ }^{-1}$ ). Bold lines represent the average value and the shaded area illustrates the range for the three mesocosms. In order to illustrate the general patterns of change rather than daily variability, the lines are loess-smoothed fits to the data. The vertical lines mark the division into the three phases.

\subsection{Synthesis and production of DMSP}

In the 6 mesocosms from which measurements were made, specific rates of DMSP synthesis ( $\mu$ DMSP) decreased during PI from between 0.20 and $0.24 \mathrm{~d}^{-1}$, to values between 0.12 and $0.13 \mathrm{~d}^{-1}$ by t12 (Fig. 4). This is equivalent to a decrease in doubling time of the DMSPt standing stocks of from $3 \mathrm{~d}$ to approaching $6 \mathrm{~d}$. Following the addition of nutrients on t13, $\mu \mathrm{DMSP}$ gradually increased amongst the mesocosms during PII and PIII to rates similar to those at the start of the experiment. No consistent relationship between $\mu \mathrm{DMSP}$ and $\left[\mathrm{H}^{+}\right]$was apparent amongst the 6 mesocosms over the full duration of the experiment (Fig. 4a). The determinations of $\mu \mathrm{DMSP}$ rates are based on the change in the mass ratio of ${ }^{13}$ C-labelled DMS versus the total DMS derived from the molar conversion of particulate DMSP (DMSPp) to DMS by alkaline hydrolysis (see methods). This determination of 


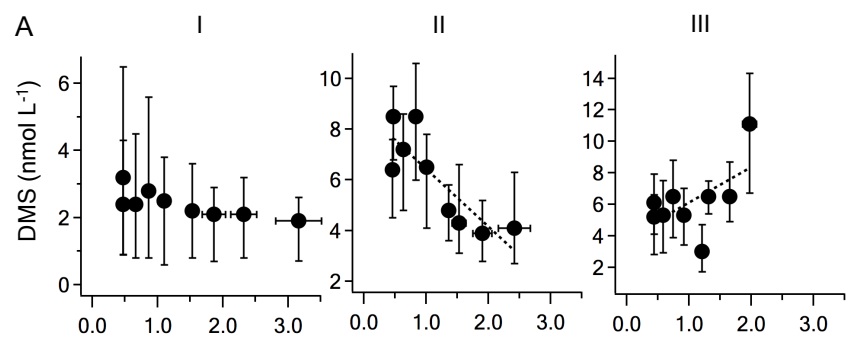

B

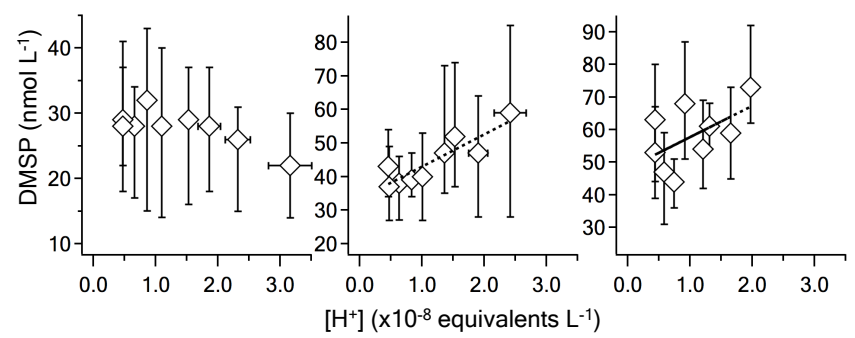

Fig. 3. Relationships between (A) DMS and (B) DMSPt and $\mathrm{H}^{+}$ concentration $\left(\left[\mathrm{H}^{+}\right]\right)$during each phase (I-III) of the experiment. Values are the mean over the duration of each phase in the nine mesocosms. Bars show the range. Significant linear regressions based on the full dataset of daily values are shown; details of which are given in Table 1 . Note $\left[\mathrm{H}^{+}\right]$decreases over the duration of the experiment in the mesocosms with higher initial concentration.

$\mu \mathrm{DMSP}$ does not require a quantitative measure of DMSPp concentration, simply the isotope ratio. In this study, the estimation of DMSP production uses the routinely measured DMSPt values from the corresponding mesocosms in order to calculate a total DMSPt production rate rather than values of DMSPp. DMSPt was the variable monitored in the mesocosms rather than DMSPp, as a result an estimate of $\mu \mathrm{DMSPt}$ is of more direct relevance that an estimate of $\mu \mathrm{DMSPp}$ in the present context.

This approach assumes that the isotope fraction is not different between DMSPt and DMSPp. This is something that could occur if the dissolved DMSP pool contained a different isotope ratio, although in this case the error is likely to be small, as the dissolved pool generally makes up only a minor fraction of the total (Kiene and Slezak, 2006). Another potential error is introduced if different pools of DMSPp contain both varied isotope ratio and vary in their susceptibility to cell damage and leakage on filtration. This is of course, also true of many routinely used particulate-based measurements, including a variety of stable and radiotracer approaches to determine element fixation and production. Despite high $\mu$ DMSP, initial DMSPt production was low due to the low DMSPt concentrations, averaging $5.2( \pm 0.8 \mathrm{SD}) \mathrm{nmol} \mathrm{L}^{-1} \mathrm{~d}^{-1}$ in the 6 mesocosms during PI (Fig. 4b). Following nutrient addition and reflecting the higher DMSPt concentrations, DMSPt production increased and became more variable between the mesocosms, rising to an average of $14.0( \pm 2.2 \mathrm{SD}) \mathrm{nmol} \mathrm{L}^{-1} \mathrm{~d}^{-1}$ by t24 (Fig. 4b).
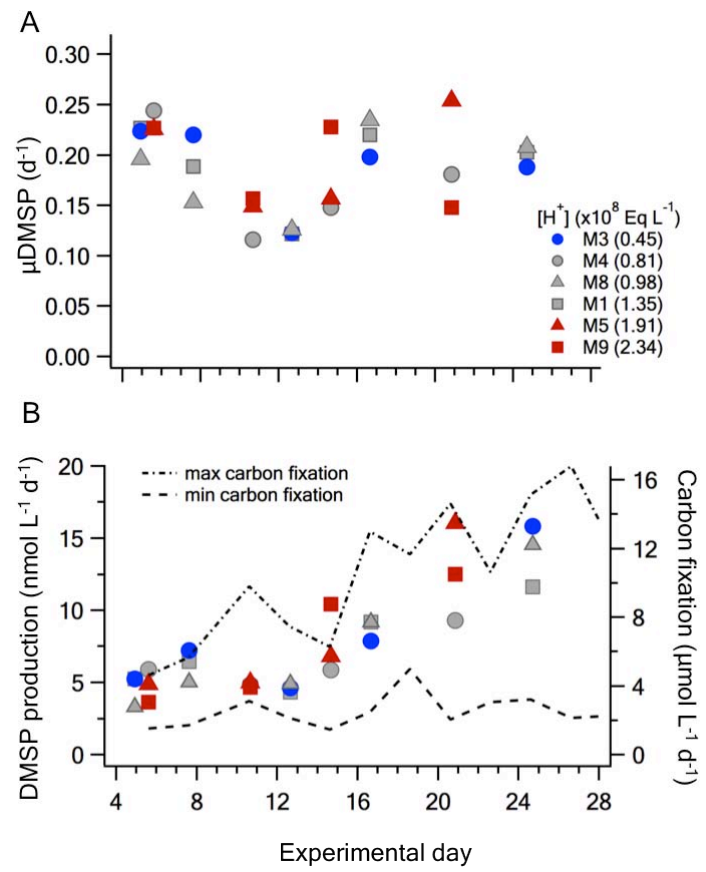

Fig. 4. Synthesis and production of DMSP in six mesocosms during the experiment: (A) specific synthesis rate ( $\mu \mathrm{DMSP})$; and (B) production of DMSPt measured over approximately $24 \mathrm{~h}$. The average $\left[\mathrm{H}^{+}\right]$for each mesocosm is shown in the legend. The pattern of carbon fixation based on ${ }^{14} \mathrm{C}$-incorporation over $24 \mathrm{~h}$ is shown as minimum and maximum values on each day amongst the nine mesocosms.

This trend closely resembles the pattern of ${ }^{14} \mathrm{C}$-based carbon fixation rates (Fig. 4b).

In order to explore the influence of acidity on rates of DMSPt and carbon production, whilst minimising variations imposed by different environmental conditions on each day, values from each experiment were normalised to the rate observed at the lowest $\left[\mathrm{H}^{+}\right]$on each date. During PII, normalised $\mu \mathrm{DMSP}$ revealed no significant correlation with $\left[\mathrm{H}^{+}\right]$(Fig. 5a). This lack of positive response in specific synthesis to increased $\left[\mathrm{H}^{+}\right]$is corroborated by the slight but significant decrease in $F_{\mathrm{v}} / F_{\mathrm{m}}$ in relation to $\left[\mathrm{H}^{+}\right]$(Fig. 5d). In contrast, both normalised DMSPt production and ${ }^{14} \mathrm{C}$ fixation increased with $\left[\mathrm{H}^{+}\right]$to similar proportions (Fig. 5b, c). For DMSPt production this was equivalent to an increase of $38 \pm 18(\mathrm{SD}) \%$ at $\left[\mathrm{H}^{+}\right]=1.67 \times 10^{-8} \mathrm{EqL}^{-1}$; corresponding to $750 \mu \mathrm{atm} p \mathrm{CO}_{2}$; whilst ${ }^{14} \mathrm{C}$ fixation increased by $43 \pm 14(\mathrm{SD}) \%$. Although DMSPt production and ${ }^{14} \mathrm{C}$ based carbon fixation showed similar relationships to $\left[\mathrm{H}^{+}\right]$, the carbon fixation invested in DMSP by the phytoplankton communities was a minor fraction of the total $(<1 \%)$ throughout the experiment. 

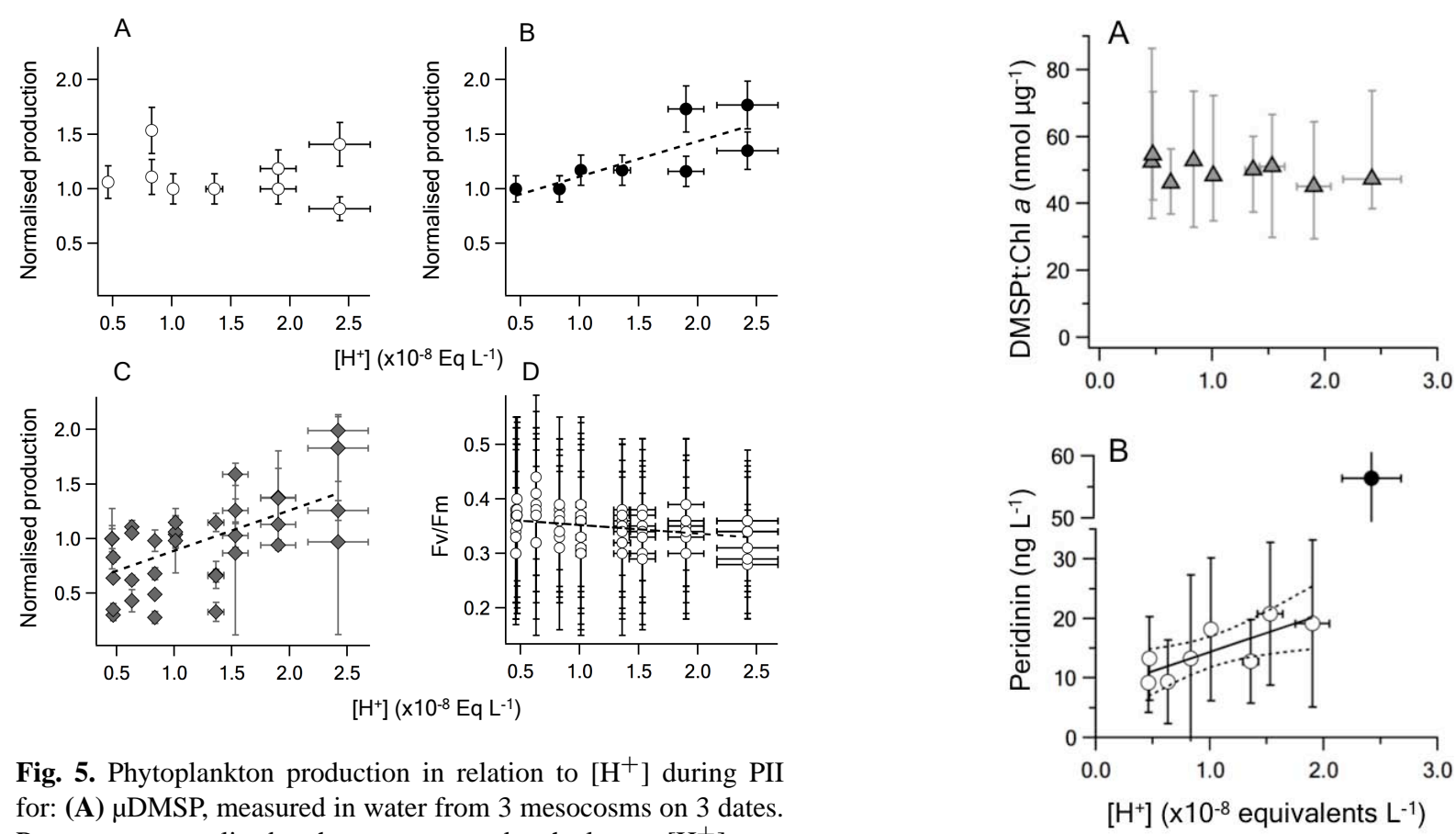

Fig. 5. Phytoplankton production in relation to $\left[\mathrm{H}^{+}\right]$during PII for: (A) $\mu$ DMSP, measured in water from 3 mesocosms on 3 dates. Rates were normalised to the rate measured at the lowest $\left[\mathrm{H}^{+}\right]$concentration on each date. Error bars show the estimated SD taking into account the precision in DMSPp concentrations and the ratio of mass $64^{-}$DMS; and SD of $\left[\mathrm{H}^{+}\right]$; and (B) normalised DMSPt production. Coefficients of the linear regression $(y=a+b x)$ are: $a=0.77( \pm 0.16 \mathrm{SE}) ; b=0.35( \pm 0.10 \mathrm{SE})(P=0.011)(n=9)$. (C) inorganic carbon fixation measured in water from nine mesocosms on four dates during PII. Rates are normalised to the rate measured in mesocosm 3 , (initially at ambient $[\mathrm{H}+]$ ). Regression coefficients are: $a=0.51( \pm 0.12 \mathrm{SE}) ; b=0.39( \pm 0.09 \mathrm{SE})(P=0.0001)$ $(n=36)$. Note values measured in mesocosm 7 , also at close to ambient $\left[\mathrm{H}^{+}\right]$, were consistently lower than in mesocosm 3. Error bars show the $\mathrm{SD}$ of carbon incorporation and of $\left[\mathrm{H}^{+}\right]$. (D) maximum potential quantum efficiency of photosystem II $\left(F_{\mathrm{V}} / F_{\mathrm{m}}\right)$. The bars represent the SD of individual measurements accounting for uncertainty in estimates of $F_{\mathrm{O}}$ and $F_{\mathrm{m}}$. Regression coefficients are: $a=0.68( \pm 0.01 \mathrm{SE}) ; b=-0.016( \pm 0.005 \mathrm{SE})(P=0.004)$ $(n=72)$.

\subsection{Taxonomic basis of DMSP production}

The difference in DMSPt production with $\left[\mathrm{H}^{+}\right]$during PII, despite no detectable increase in $\mu \mathrm{DMSP}$, may reflect alterations in taxonomic composition of the phytoplankton. A change in the proportion of phytoplankton that produced DMSP may be apparent in the ratio of DMSPt to chlorophyll $a$. However, DMSPt:chl $a$ was consistently low amongst the mesocosms during all phases, averaging

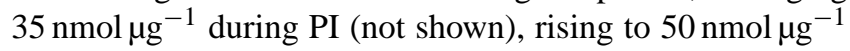
during PII , but with no relationship to $\left[\mathrm{H}^{+}\right]$(Fig. 6a); and decreasing on average to $38 \mathrm{nmol} \mathrm{\mu g}^{-1}$ in PIII (not shown). During PIII average DMSPt:chl $a$ in the mesocosms was significantly $(P<0.05)$ related to $\left[\mathrm{H}^{+}\right]$, driven to a large extent by decreases at lower $\left[\mathrm{H}^{+}\right]$(not shown). The low

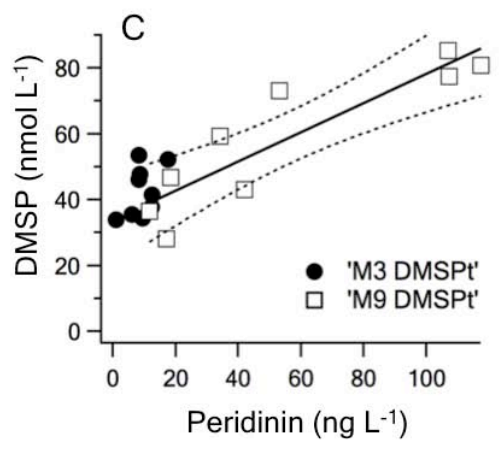

Fig. 6. Pigment concentrations in relation to DMSPt and acidification during PII: (A) DMSPt:chl $a$ ratio versus $\left[\mathrm{H}^{+}\right]$. Values for DMSPt:chl $a$ are the mean during PII in each mesocosm, bars show the range. Values for $\left[\mathrm{H}^{+}\right]$are the mean \pm SD. (B) Peridinin versus $\left[\mathrm{H}^{+}\right]$. Values for peridinin and $\left[\mathrm{H}^{+}\right]$are mean $\pm \mathrm{SD}$. Coefficients of the linear regression $(y=a+b x)$ based on the full dataset $(n=63): a=7.7$ ( $\pm 2.9 \mathrm{SE}), b=7.3( \pm 2.6 \mathrm{SE}),(P=0.007)$. Note values from the highest $\left[\mathrm{H}^{+}\right]$are not included in the regression. (C) DMSPt versus peridinin concentrations in mesocosm 3 (not significant) and mesocosm 9. Coefficients of the linear regression are: $a=34$ ( $\pm 6 \mathrm{SE}), b=0.44( \pm 0.08 \mathrm{SE}) ;(P=0.001)$. The dotted lines show the $95 \%$ confident intervals in each case.

DMSPt:chl $a$ ratios are consistent with the low proportion of carbon fixation invested in DMSP synthesis.

Although DMSP:chl $a$ did not vary amongst the mesocosms in PII, specific marker pigments reveal changes in taxonomic composition that may be related to the different DMSPt production. Concentrations of the dinoflagellatespecific pigment peridinin were consistently lower than $10 \mathrm{ng} \mathrm{L}^{-1}$ during PI, suggesting that dinoflagellate biomass 

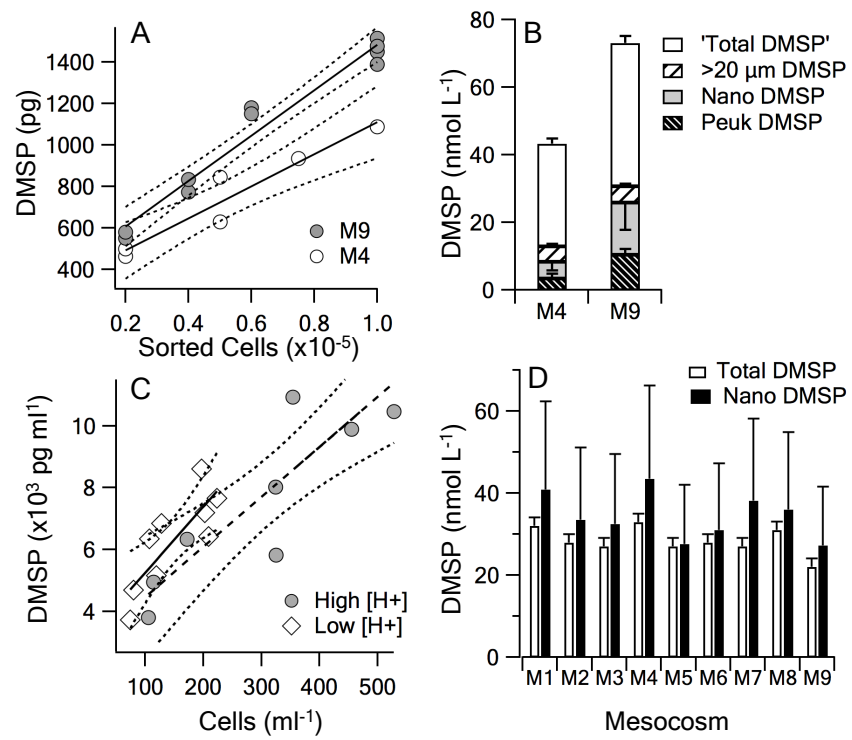

Fig. 7. Contributors to DMSP production: (A) differences in the DMSP content of picoeukaryote phytoplankton sorted by flow cytometry collected from mesocosm 4 and mesocosm 9 on $t 21$. Coefficients $( \pm \mathrm{SD})$ of the linear regression are: M4, $y=340( \pm 190)+0.008( \pm 0.003) x ;$ M9, $y=390$ $( \pm 130)+0.011( \pm 0.002) x$. (B) Components of DMSP during PII on t18 in mesocosm 4 and mesocosm 9 when picoeukaryote abundance was highest; Peuk: picoeukaryote; Nano: nanoeukaryote; $>20 \mu \mathrm{m}$ : component retained by a $20 \mu \mathrm{m}$ filter. The Peuk component was based on abundance and cell-specific DMSP-content measured on $\mathrm{t} 21$; the Nano component was based on abundance and the range of values obtained in North Atlantic waters (Archer et al., 2011). (C) Abundance of Heterocapsa rotundata versus DMSPt concentration in mesocosms 5 and 9 during PII. The fitted regressions are: M9, $y=2.85( \pm 1.11)+0.016( \pm 0.003) x$; and M5, $y=3.12( \pm 0.90)+0.021( \pm 0.005) x$. (D) Estimated contribution of nanoeukaryotes (Nano) to DMSP during PI. Values for total DMSP are the mean and range during PI, values for Nano DMSP are based on the mean and range of cell-specific values (0.96 (0.5-1.6) pg DMSP cell ${ }^{-1}$ ) measured in North Atlantic waters (Archer et al., 2011). The dotted lines mark the $95 \%$ confidence intervals for each linear regression.

was low (not shown). However, values increased during PII, and the increased concentrations were significantly related to $\left[\mathrm{H}^{+}\right]$(Fig. 6b). Considerably higher levels occurred at the highest $\left[\mathrm{H}^{+}\right]$, in mesocosm 9, than in any of the other mesocosms. The important contribution by dinoflagellates to the higher DMSPt concentrations at higher $\left[\mathrm{H}^{+}\right]$during PII is supported by the strong relationship between each for mesocosm 9 (highest $\left[\mathrm{H}^{+}\right]$) compared to mesocosm 3 (ambient $\left[\mathrm{H}^{+}\right]$) (Fig. 6c).

Picoeukaryotes were the numerically dominant phytoplankton during PII and showed a significant positive response to $\left[\mathrm{H}^{+}\right](y=16.4+38.7(P<0.05)$; where $y=$ $\times 10^{6}$ cells $\mathrm{L}^{-1}$ and $x=[H+], \times 10^{8}$ equivalents $\left.\mathrm{L}^{-1}\right)$. Flow cytometric sorting conducted on the last day of PII revealed differences in the DMSPt content of picoeukaryote cells, with cells from mesocosm $9\left(\left[\mathrm{H}^{+}\right]=2.42 \times 10^{8}\right.$ equivalents $\mathrm{L}^{-1}$ ) having a DMSP content of $0.011( \pm 0.002) \mathrm{pg} \mathrm{cell}^{-1}$ and mesocosm $4\left(\left[\mathrm{H}^{+}\right]=0.83 \times 10^{8}\right.$ equivalents $\left.\mathrm{L}^{-1}\right)$ cells containing $0.008( \pm 0.003) \mathrm{pg} \mathrm{cell}^{-1}$ (Fig. 7a). When these values are used to calculate the contribution to DMSPt at the height of picoeukaryote abundance on $\mathrm{t} 18$, they indicate a contribution of between 8 and $14 \%$ to the total. The bulk of the remaining DMSPt was not accounted for by the flow cytometrically defined nanoeukaryote population or by cells of $>20 \mu \mathrm{m}$ (Fig. 7b). All three components combined to contribute approximately $13 \mathrm{nmol} \mathrm{L}^{-1}$ in mesocosm 4 and $31 \mathrm{nmol} \mathrm{L}^{-1}$ in mesocosm 9 . The latter value is confirmed by the intercept of the regression between peridinin and DMSP for mesocosm 9 during PII (Fig. 6c). Instead, the remaining DMSPt is likely to have been contained in cells of $<20 \mu \mathrm{m}$ that were not included in the nanoeukaryote population that was defined on the flow cytograms. A strong dependence between flow cytometric counts of the dinoflagellate Heterosigma rotundata $(\sim 10 \mu \mathrm{m}$ in length) and DMSPt indicates that the increased abundance of this species at higher $\left[\mathrm{H}^{+}\right]$, for instance in mesocosm $5\left(\left[\mathrm{H}^{+}\right]=1.90 \times 10^{8}\right.$ equivalents $\left.\mathrm{L}^{-1}\right)$ and mesocosm $9\left(\left[\mathrm{H}^{+}\right]=2.42 \times 10^{8}\right.$ equivalents $\mathrm{L}^{-1}$ ), was responsible for the differences in DMSPt between mesocosms during PII (Fig. 7c). If it is assumed that the temporal differences in DMSPt within the mesocosms is due to H. rotundata abundance, then the slope of the regression provides an estimate of the DMSP content per cell of between 16 and 21 pg DMSP cell ${ }^{-1}$ (Fig. 7c).

\subsection{Bacterial production and DMS}

The proportion of DMSPt converted to DMS is, in part, reliant on the yield of DMS from bacterial metabolism of DMSPd. The dependence of the concentration of DMS on bacterial metabolism was investigated indirectly by comparing bacterial production to the ratio of DMS:DMSPt. Over the course of the experiment bacterial production determined from the incorporation rate of leucine appeared to be more closely related to the DMS:DMSPt ratio at higher $\left[\mathrm{H}^{+}\right]$ than at ambient $\left[\mathrm{H}^{+}\right]$(Fig. 8). This is reflected in the increasing levels of correlation $(r)$ between daily values of DMS:DMSPt and bacterial production, with approximately $60 \%$ of the variability in DMS:DMSPt explained by bacterial production at the highest levels of $\left[\mathrm{H}^{+}\right]$(Table 2). A significant linear relationship between DMS:DMSPt and bacterial production occurred in the three high $\left[\mathrm{H}^{+}\right]$mesocosms (Table 2); further indicating a greater regulatory role by bacteria on DMS concentration at increased $\left[\mathrm{H}^{+}\right]$. The Durbin-Watson statistic confirmed that significant autocorrelation $(P<0.05)$ did not influence the significance of the linear relationship in the three high $\left[\mathrm{H}^{+}\right]$mesocosms (Table 2). 
Table 2. Significance of the relationship between bacterial production and the DMS:DMSPt ratio during the experiment for each mesocosm and corresponding $\left[\mathrm{H}^{+}\right]\left(\times 10^{-8} \mathrm{Eq} \mathrm{L}^{-1}\right)$. Values are the Pearson correlation coefficient $(r)$, the coefficient of determination $\left(r^{2}\right)$ and the significance of the linear relationship: F-ratio of the ANOVA of the linear regression (Significance: $* P<0.05$, $* * * P<0.001)(n=16)$. The Durbin-Watson statistic computed for mesocosms 6,5 and 9 was higher than the critical value (upper limit $1.371, n=16$ ) confirming limited autocorrelation in the data and the validity of the significance values of $F$.

\begin{tabular}{lrrrr}
\hline Mesocosm \# & {$\left[\mathrm{H}^{+}\right]$} & $r$ & $r^{2}$ & Significance of $F$ \\
\hline 3 & 0.46 & 0.29 & 0.09 & 0.27 \\
7 & 0.47 & 0.00 & 0.00 & 0.99 \\
2 & 0.63 & 0.28 & 0.08 & 0.30 \\
4 & 0.83 & 0.21 & 0.04 & 0.44 \\
8 & 1.01 & 0.22 & 0.05 & 0.42 \\
1 & 1.36 & -0.47 & 0.22 & 0.07 \\
6 & 1.53 & $0.59^{* * *}$ & 0.34 & $0.02^{*}$ \\
5 & 1.90 & $0.78^{* * *}$ & 0.61 & $0.00^{* * *}$ \\
9 & 2.42 & $0.75^{* * *}$ & 0.57 & $0.00^{* * *}$ \\
\hline
\end{tabular}

\section{Discussion}

The DMSP and DMS response during the EPOCA experiment showed broad similarities to mesocosm and shipboard experiments carried out in temperate waters (Table 3). In common with most mesocosm experiments in temperate waters, the addition of nutrients during the EPOCAmesocosm experiment stimulated phytoplankton production, driving patterns of change in the microbial communities characteristic of seasonal phytoplankton blooms and their succession. Stimulation of autotrophic and heterotrophic production was accompanied by variations in DMS and DMSP concentrations of approximately an order of magnitude; similar to observations of seasonal changes in Arctic waters (Leck and Persson 1996; Bouillon et al., 2002). During PII of the EPOCA mesocosm experiment, variations in composition and/or physiology of natural Arctic microbial communities resulted in daily average concentrations of DMS that were $35( \pm 11) \%$ lower at $\left[\mathrm{H}^{+}\right]$concentrations that are projected to occur in 2100 , compared to present conditions. This response was largely the result of variations in acidity. Similar levels of response have been observed in temperate waters, with similar variations in $\left[\mathrm{H}^{+}\right]$altering time-integrated or average concentrations of DMS by approximately $\pm 50 \%$ (Table 3). At the very least, different levels of $\left[\mathrm{H}^{+}\right]$have changed the temporal patterns of DMS concentration between mesocosms (Vogt et al., 2008). A reproducible response of decreased DMS with increased $\left[\mathrm{H}^{+}\right]$appears to occur when nutrient-stimulated blooms develop in mesocosms in Norwegian coastal waters (Hopkins et al., 2010; Avgoustidi et al., 2012). The following section explores what drove the variations in DMS and DMSP concentration during the

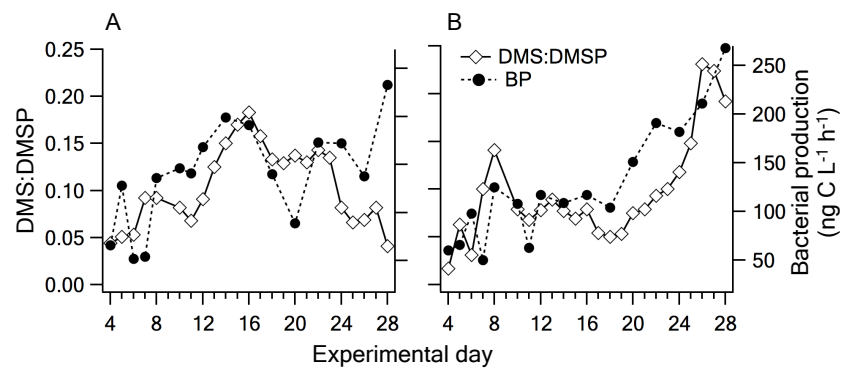

Fig. 8. Temporal trends in the molar ratio of DMS:DMSPt and bacterial production (BP) measured in mesocosm 3 (close to ambient $\left[\mathrm{H}^{+}\right]$) and mesocosm 9 (highest $\left[\mathrm{H}^{+}\right]$).

Arctic experiment; whether the underlying causes of the response can be generalised; and what inferences can be drawn from these results in terms of aerosol formation and atmospheric chemistry in the Arctic.

During the EPOCA experiment, varied $\left[\mathrm{H}^{+}\right]$treatments had a more obvious influence on DMSP concentrations, phytoplankton composition and biomass following nutrient addition (PII) compared to the initial nutrient-deplete postbloom environment (PI). Phytoplankton compositional differences during PIII were driven in part by residual variations in nutrient availability following the different magnitude blooms during PII (Schulz et al., 2013). This made it difficult to confidently assign observed variations in DMSP or DMS responses during PIII to $\left[\mathrm{H}^{+}\right]$. During PI (t4 to t12), pigment analyses indicate that the nanoflagellate population that dominated cell abundance was composed primarily of haptophytes that contributed approximately $50 \%$ of the chlorophyll $a$ concentrations (Schulz et al., 2013). The haptophyte group includes species with sufficiently high DMSP cell content, of approximately $1 \mathrm{pg}$ DMSP cell $^{-1}$ (Keller et al., 1989), to explain the total DMSPt concentrations observed during PI (Fig. 7d). The lack of a significant difference in DMSPt in relation to $\left[\mathrm{H}^{+}\right]$during PI is consistent with observed patterns of nanoflagellate abundance and pigment-based estimates of haptophyte abundance that also showed no significant differences (Schulz et al., 2013). Haptophytes possess the type I form of RubisCO (ribulose-1, 5-bisphosphate carboxylase-oxygenase) that has a higher affinity for dissolved aqueous $\mathrm{CO}_{2}\left(\mathrm{CO}_{2} \mathrm{aq}\right)$ and, as a result, may be less susceptible to direct enhancement of carbon fixation due to increased $p \mathrm{CO}_{2}$ (Reinfelder, 2011). However, they vary markedly in the efficiency of the carbon concentrating mechanism (CCMs) that they employ and this is likely to reflect the extent to which increased $p \mathrm{CO}_{2}$ and hence $\mathrm{CO}_{2}$ aq availability enhances productivity (Rost et al., 2008), including DMSP production. In mesocosms in Norwegian coastal waters the specific net growth rates and calcification rates of the coccolithophorid haptophyte Emiliania huxleyi, which dominated the phytoplankton, decreased with increased $p \mathrm{CO}_{2}$ (Engel et al., 2005). 
Table 3. Summary of responses of DMS and DMSP to altered $p \mathrm{CO}_{2}$ in natural waters.

\begin{tabular}{|c|c|c|c|c|}
\hline Location & $\begin{array}{r}p \mathrm{CO}_{2} \text { range } \\
\text { (and temperature) }\end{array}$ & $\begin{array}{l}\% \text { DMS change } \\
\text { from present }\end{array}$ & $\begin{array}{r}\% \text { DMSP change } \\
\text { from present }\end{array}$ & Study \\
\hline $\begin{array}{l}\text { Norwegian coastal } \\
\text { mesocosm }\end{array}$ & 300 vs. $750 \mu \mathrm{atm}$ & $\begin{array}{l}\sim 40 \% \text { lower } \\
\quad(P<0.05)^{1}\end{array}$ & $\begin{array}{l}40 \% \text { lower } \\
\quad(P<0.05)^{1}\end{array}$ & $\begin{array}{l}\text { Avgoustidi } \\
\text { et al. (2012) }\end{array}$ \\
\hline $\begin{array}{l}\text { Norwegian coastal } \\
\text { mesocosm }\end{array}$ & $\begin{array}{r}300 \text { vs. } 750 \\
\text { vs. } 1050 \mu \text { atm }\end{array}$ & $\begin{array}{r}\text { not significantly } \\
\text { different at } \\
(P<0.05)^{1}\end{array}$ & $\begin{array}{r}\text { not significantly } \\
\text { different at } \\
(P<0.05)^{1}\end{array}$ & $\begin{array}{l}\text { Vogt et al. } \\
\quad(2008)^{2}\end{array}$ \\
\hline $\begin{array}{l}\text { Norwegian coastal } \\
\text { mesocosm }\end{array}$ & 350 vs. $750 \mu \mathrm{atm}$ & $54 \%$ lower $^{3}$ & $24 \%$ lower $^{3}$ & $\begin{array}{r}\text { Hopkins } \\
\text { et al. (2010) }\end{array}$ \\
\hline $\begin{array}{l}\text { Korean coastal } \\
\text { mesocosm }\end{array}$ & $\begin{array}{r}400 \mu \mathrm{atm} \text { vs. } \\
900 \mu \mathrm{atm} \mathrm{vs} . \\
900 \mu \mathrm{atm}+3^{\circ} \mathrm{C}\end{array}$ & $\begin{array}{l}80 \% \text { higher }^{1} \\
60 \% \text { higher }^{1}\end{array}$ & $\begin{array}{r}\text { increased } \\
\text { DMSP:POC }\end{array}$ & $\begin{array}{r}\text { Kim et al. } \\
\text { (2010) }\end{array}$ \\
\hline $\begin{array}{l}\text { North Atlantic } \\
\text { Ecostat approach }\end{array}$ & $\begin{array}{r}390 \mu \mathrm{atm} v \mathrm{~s} . \\
690 \mu \mathrm{atm} \text { vs. } \\
690 \mu \mathrm{atm}+4{ }^{\circ} \mathrm{C}\end{array}$ & $\begin{array}{l}\text { No data } \\
\text { No data }\end{array}$ & $\begin{array}{r}\text { No effect } \\
2-4 \text { fold higher }\end{array}$ & $\begin{array}{r}\text { Lee et al. } \\
(2009)\end{array}$ \\
\hline $\begin{array}{l}\text { Arctic coastal } \\
\text { pelagic mesocosms }\end{array}$ & 190 to $750 \mu \mathrm{atm}$ & $\begin{array}{r}35( \pm 11) \% \\
\text { lower } 4 \\
(P<0.005)\end{array}$ & $\begin{array}{r}30( \pm 3) \% \\
\text { higher }^{4} \\
(P<0.005)\end{array}$ & This study \\
\hline
\end{tabular}

${ }^{1}$ Time-integrated values over the course of the experiment. ${ }^{2}$ Significant differences in DMS concentrations reported from the same study at $P<0.10$ level (Wingenter et al., 2007). ${ }^{3}$ Average concentration during the peak of the phytoplankton bloom. ${ }^{4}$ Time-integrated concentrations following nutrient addition (PII); note the values are restricted to the change over $p \mathrm{CO}_{2} 190$ to $750 \mu$ atm range, not the full 190 to $1400 \mu \mathrm{atm}$ range of the experiments.

A similar negative response to raised $p \mathrm{CO}_{2}$ amongst the DMSP-producing phytoplankton may have been responsible for reduced chlorophyll $a$, DMSP and DMS concentrations in the similar experiment at the same location described by Hopkins et al. (2009).

In contrast, during PII (days 13 to 21 ), raised $\mathrm{CO}_{2}$ aq availability appeared to stimulate the net growth of autotrophic picoeukaryotes and dinoflagellates (Fig. 6). Although the DMSP content of picoeukaryotes showed an interesting variation between mesocosms that warrants further investigation, they made only a minor contribution to total DMSPt (Fig. 7). The strong relationship between peridinin and DMSPt concentrations and more specifically between the abundance of the dinoflagellate Heterocapsa rotundata and DMSPt (Figs. 6c and 7c), indicates that dinoflagellates were responsible for the bulk (60-70\%) of the DMSP standing stock during PII (Fig. 7c) and for the differences in DMSPt accumulation between levels of $\left[\mathrm{H}^{+}\right]$. Autotrophic dinoflagellates possess type II RubisCO, which has the lowest effective affinity for $\mathrm{CO}_{2}$ aq amongst eukaryotic phytoplankton, giving dinoflagellates a disadvantage with respect to carbon fixation in the high- $\mathrm{O}_{2}$, low- $\mathrm{CO}_{2}$ modern ocean (Reinfelder, 2011). Dinoflagellates possess a variety of CCM strategies, including their capacity to indirectly utilize $\mathrm{HCO}_{3}^{-}$ through acclimation of carbonic anhydrase activity (Rost et al., 2006). Elevated $\mathrm{CO}_{2}$ aq availability at high $\left[\mathrm{H}^{+}\right]$may have decreased the metabolic costs associated with carbon concentration sufficiently to enable dinoflagellates, and $H$. rotundata in particular, to grow at a higher rate and produce elevated DMSPt concentrations. Although the authors are aware of no direct measurements of the DMSP cell content of $H$. rotundata, values for closely related species do exist. Intracellular DMSP concentration amongst the genus Heterocapsa is typical of dinoflagellates, varying from 190 to $450 \mathrm{mmol} \mathrm{L}^{-1}$ in the four species studied (Keller et al., 1989; Niki et al., 2000; Caruana, 2010). Assuming an average value of $320 \mathrm{mmol} \mathrm{L}^{-1}$ for $H$. rotundata and a cell volume between 130 and $340 \mu^{-3}$ (Olenina et al., 2006) provides an estimated cell content of 6-15 pg DMSP cell ${ }^{-1}$. A similar value of 16 to $25 \mathrm{pg}$ DMSP cell $^{-1}$ can be estimated from the regression analyses of DMSPt versus $H$. rotundata abundance in two different mesocosms (Fig. 7c). This confirms the important, but not exclusive, contribution of this species to the $\left[\mathrm{H}^{+}\right]$-related variations in DMSPt.

Several explanations for the reduced DMS concentrations despite increased DMSPt production at elevated $\left[\mathrm{H}^{+}\right]$during PII can be considered. As stated previously, multiple processes transform phytoplankton DMSP to the dissolved phase including active exudation, cell lysis during senescence, viral lysis and grazing by zooplankton (Stefels et al., 2007). The proportion of DMS produced via these processes is in part a product of the affinity of algal enzymes capable of cleaving DMSP to DMS and acrylate, or DMSP-lyase activity (DLA) (Stefels et al., 1995; Steinke et al., 2002). How 
algal DLA influences DMS production remains poorly understood but increasingly appears to be an important factor governing seawater DMS concentrations (Archer, 2007; Gali et al., 2011). DLA activity measured in microalgal cell homogenates or in extracellular assays varies considerably between species (Niki et al., 2000; Franklin et al., 2010), and even amongst laboratory isolates of single species (Steinke et al., 1998). No known rates of the DMS-producing capacity of $H$. rotundata are available but separate studies of the DLA activity in the closely related species Heterocapsa triquetra provide contrasting evidence of either no detectable capacity (Caruana, 2010) or relatively high DMSproducing potential (Niki et al., 2000). Different laboratory strains and different DLA-assay methods were used in the two studies, possibly explaining the variation. As H. rotundata abundance was largely responsible for the increased DMSPt present at high $\left[\mathrm{H}^{+}\right]$, it is possible that it had low DLA activity compared to other taxa that contributed to the DMSPt pool, partially accounting for the decreased DMS concentrations at high $\left[\mathrm{H}^{+}\right]$.

Production rates of DMS are partly dependent on the turnover of DMSPt. As $\mu$ DMSP rates did not vary significantly in relation to $\left[\mathrm{H}^{+}\right]$(Fig. 5a), the increased DMSPt concentrations at elevated $\left[\mathrm{H}^{+}\right]$(Fig. 3) must have resulted from reduced loss rates of DMSPt. Based on indirect evidence, Kim et al. (2010) suggested elevated grazing, possibly in response to higher phytoplankton growth rates, may have raised DMS concentrations at higher $p \mathrm{CO}_{2}$ in a mesocosm experiment conducted in Korean waters (Table 1). In contrast, in Arctic waters, grazing or viral lysis of $H$. roundata may have been lower than on the picoeukaryote and nanoflagellate components of the DMSPt pool during PII. If so, this may explain reduced turnover of the total DMSPt pool at higher $\left[\mathrm{H}^{+}\right]$, resulting in reduced transformation of phytoplankton DMSP to the dissolved phase, including DMS production.

Bacterial metabolism may also have contributed to the differences in DMS concentration between levels of $\left[\mathrm{H}^{+}\right]$. Radiolabelled tracer studies have shown that pelagic bacteria generally either cleave DMSP, generating DMS, or demethylate/demethiolate DMSP to methylmercaptopropionate and methanethiol (Kiene et al., 2000). The former provides a 3Ccompound for carbon or energy use, whilst the $\mathrm{CH}_{3}-\mathrm{S}$ group generated from demethylation may be an energetically efficient route for $\mathrm{S}$-containing protein biosynthesis. The relative magnitude of these catabolic pathways determines the DMS yield from dissolved DMSP consumption, which has been hypothesised to be a product of the sulphur demand of the bacteria (Kiene et al., 2000). Conditions that enhance bacterial production may result in a decreased yield of DMS as the requirement to synthesise S-containing proteins increases the demethylation of DMSP. Variations in bacterial protein production were directly related to differences in primary production amongst the mesocosms during the EPOCA experiment (Piontek et al., 2013). Increased primary produc- tion at higher $\left[\mathrm{H}^{+}\right]$, including DMSPt production (Fig. 5), partially stimulated bacterial protein production, potentially generating a greater demand for DMSP-sulphur and, therefore, a reduced production of DMS. The suggestion of increased DMSP-sulphur demand at high $\left[\mathrm{H}^{+}\right]$is supported by the stronger correlations between DMS:DMSPt ratio and bacterial protein production (Table 2).

An additional factor, more difficult to ascertain without direct measurements, is the contribution of bacterial DMS metabolism to decreased DMS concentrations at high $\left[\mathrm{H}^{+}\right]$ during PII. Bacterial DMS consumption is likely to have been the major DMS removal process in the mesocosms. Photolysis of DMS is primarily driven by UV-wavelengths and therefore would have been minimal in the mesocosms as the walls and covers were UV-opaque. Based on direct measurements of gas transfer velocities in the mesocosms (J. Czerny, personal communication, 2012), sea-to-air flux of DMS (not shown) averaged a loss of only $2 \% \mathrm{~d}^{-1}$ of the DMS standing stocks and so had a minimal impact on variations in DMS concentrations. Future ocean acidification studies that combine rate measurements of DMSP and DMS metabolism with the increasing understanding of the genetic basis of DMSP and DMS catabolism (Curson et al., 2011; Reisch et al., 2011), are likely to throw more light on the role of bacteria in regulating DMS concentrations.

To what extent DMS emissions contribute to the optically thin, low lying clouds that are present for approximately $90 \%$ of the time during summer in the Arctic (Curry, 1995), is unclear. Cloud formation in this environment is limited by the availability of cloud condensation nuclei, and is therefore sensitive to alterations in the source strength of aerosol particles (Mauritsen et al., 2011). The small Aitken mode particles that dominate the aerosol composition during summer months are thought to be a product of local sources of primary biogenic and secondary aerosol formation, including $\mathrm{H}_{2} \mathrm{SO}_{4}$ derived from DMS emissions; in addition to increased solar radiation that drives the required photochemistry (Korhonen et al., 2008; Orellana et al., 2011). The net effect of low level cloud formation in the Arctic summer is warming at the surface (Intrieri et al., 2002; Mauritsen et al., 2011). If reduced DMS emissions are a widespread consequence of ocean acidification in the Arctic then it may contribute a negative feedback to the general warming. How the magnitude of this effect compares with the contrasting projected increases in primary biogenic and sea-salt aerosol sources associated with expanding areas of open water in summer months (Held et al., 2011; Kay et al., 2011), constitutes an additional facet of the poorly understood and complex ocean-atmosphere interactions and radiation budgets in the Arctic. 


\section{Conclusions}

Modelling studies vary substantially in predictions of the magnitude of change in DMS emissions from polar waters; suggesting increases in DMS emission of 30 to $>150 \%$ at the highest latitudes. (Gabric et al., 2005; Kloster et al., 2007; Cameron-Smith et al., 2011). These increases are due to a combination of increased net primary production and regional shifts in community composition that potentially result from sea ice retreat and changes in temperature, mixing, nutrient availability and light levels. The present study illustrates that alterations in concentration, and hence seato-air flux, of DMS due to ocean acidification in the summer in Artic shelf-seas may be of a comparable magnitude but opposing direction. This emphasises the need to incorporate ocean acidification in future modelling assessments. Moreover, the experimental design of eight treatment levels provides comparatively robust empirical relationships of DMS and DMSP concentration versus $\left[\mathrm{H}^{+}\right]$. These are likely to be of value to parameterize or validate DMS-ocean acidification modelling studies.

Clearly, during PII, when the influence of altered acidity was most straightforward to interpret, increased $\left[\mathrm{H}^{+}\right]$and corresponding increases in $\mathrm{CO}_{2}$ aq availability coincided with increased gross primary production; a component of which was the raised net production of an autotrophic dinoflagellate and elevated DMSP production and standing stocks. Why the increased DMSP production was not transformed into higher DMS concentrations at increased levels of $\left[\mathrm{H}^{+}\right]$is less clear. This may have been a function of both reduced algal DMSPcleavage capacity and increased bacterial demand for DMSP driven by elevated bacterial production associated with the raised primary production at increased $\left[\mathrm{H}^{+}\right]$. Understanding how representative the decreases in DMS concentrations observed during PII are of ocean acidification-driven changes in the Arctic requires further investigation. Additional multidisciplinary experimental studies, aimed at unravelling the ecophysiological factors responsible for changes in the composition of microbial populations that impact on the production and cycling of DMSP and DMS, are now required. Fully understanding the processes involved in determining DMS concentrations in natural waters is a major undertaking and something that has been partially achieved in only a handful of locations by relatively large teams (Bates et al., 1994; Archer et al., 2002; Bailey et al., 2008). Modelling and observational tools need to be more closely coupled to identify the key processes and how they may alter in the face of environmental forcing. Only once these key processes are fully understood are we likely to be able to confidently use mechanistic models to predict how ocean acidification and other stressors are going to affect DMS emissions.

Acknowledgements. This work is a contribution to the European Project on OCean Acidification (EPOCA), which received funding from the European Community's Seventh Framework
Programme (FP7/2007-2013) under grant agreement no. 211384. Additional financial support was provided through the European Centre for Arctic Environmental Research (ARCFAC) (grant number ARCFAC026129-2009-140, awarded to SDA, SAK and FEH) and through Transnational Access funds by the EU project MESOAQUA under grant agreement no. 22822. We gratefully acknowledge the logistical support of Greenpeace International for its assistance with the transport of the mesocosm facility from Kiel to Ny-Ålesund and back to Kiel. We also thank the captains and crews of M/V ESPERANZA of Greenpeace and R/V Viking Explorer of the University Centre in Svalbard (UNIS) for assistance during mesocosm transport and during deployment and recovery in Kongsfjorden. We are grateful to the UK Natural Environmental Research Council for the accommodation and support provided through the NERC-BAS station in Ny-Ålesund. We also thank the staff of the French-German Arctic Research Base at Ny-Ålesund, in particular Marcus Schuhmacher, for on-site logistical support. Finally, we would like to thank Ulf Riebesell, Sebastian Krug and the whole of the Svalbard mesocosm team, who showed great team spirit and comradeship and helped to make the experiment both enjoyable and successful.

Edited by: U. Riebesell

\section{References}

Archer, S. D., Gilbert, F. J., Nightingale, P. D., Zubkov, M. V., Taylor, A. H., Smith, G. C., and Burkill, P. H.: Transformation of dimethylsulphoniopropionate to dimethyl sulphide during summer in the North Sea with an examination of key processes via a modelling approach, Deep-Sea Res. II, 49, 3067-3101, 2002.

Archer, S. D.: Crucial uncertainties in predicting biological control of DMS emission, Environ. Chem., 4, 404-405, 2007.

Archer, S. D., Tarran, G. A., Stephens, J. A., Butcher, L. J., and Kimmance, S. A.: Combining cell sorting with gas chromatography to determine phytoplankton group-specific intracellular dimethylsulphoniopropionate, Aq. Micro. Ecol., 62, 109-121, 2011.

Avgoustidi, V., Nightingale, P. D., Joint, I., Steinke, M., Turner, S. M., Hopkins, F. E., and Liss, P. S.: Decreased marine dimethyl sulfide production under elevated $\mathrm{CO}_{2}$ levels in mesocosm and in vitro studies, Environ. Chem., 9, 399-404, 2012.

Bailey, K. E., Toole, D. A., Blomquist, B., Najjar, R. G., Huebert, B., Kieber, D. J., Kiene, R. P., Matrai, R., Westby, G. R., and del Valle, D. A.: Dimethylsulfide production in Sargasso Sea eddies, Deep-Sea Res. II, 55, 1491-1504, 2008.

Bates, T. S., Kiene, R. P., Wolfe, G. V., Matrai, P. A., Chavez, F. P., Buck, K. R., Blomquist, B. W., and Cuhel, R. L.: The Cycling of Sulfur in Surface Seawater of the Northeast Pacific, J. Geophys. Res.-Oc., 99, 7835-7843, 1994.

Bellerby, R. G. J., Silyakova, A., Nondal, G., Slagstad, D., Czerny, J., de Lange, T., and Ludwig, A.: Marine carbonate system evolution during the EPOCA Arctic pelagic ecosystem experiment in the context of simulated Arctic ocean acidification, Biogeosciences, in press, 2013.

Bigg, E. K. and Leck, C.: The composition of fragments of bubbles bursting at the ocean surface, J. Geophys. Res.-Atmos., 113, D11209, doi:10.1029/2007JD009078, 2008. 
Bouillon, R. C., Lee, P. A., de Mora, S. J., Levasseur, M., and Lovejoy, C.: Vernal distribution of dimethylsulphide, dimethylsulphoniopropionate, and dimethylsulphoxide in the North Water in 1998, Deep-Sea Res. II, 49, 5171-5189, 2002.

Caldeira, K. and Wickett, M. E.: Anthropogenic carbon and ocean pH, Nature, 425, 365-365, 2003.

Cameron-Smith, P., Elliott, S., Maltrud, M., Erickson, D., and Wingenter, O.: Changes in dimethyl sulfide oceanic distribution due to climate change, Geophys. Res. Lett., 38, L07704, doi:10.1029/2011GL047069, 2011.

Carpenter, L. J., Archer, S. D., and Beale, R.: Ocean-atmosphere trace gas exchange, Chem. Soc. Rev., 41, 6473-6506, 2012.

Caruana, A.: DMS and DMSP production by marine dinoflagellates, University of East Anglia, Doctor of Philisophy, 2010.

Chen, T. Y. and Jang, M.: Secondary organic aerosol formation from photooxidation of a mixture of dimethyl sulfide and isoprene, Atmos. Environ., 46, 271-278, 2012.

Curry, J. A.: Interactions among aerosols, clouds and climate of the Arctic-Ocean, Sci. Total Environ., 160, 777-791, 1995.

Curry, J. A., Rossow, W. B., Randall, D., and Schramm, J. L.: Overview of Arctic cloud and radiation characteristics, J. Clim., 9, 1731-1764, 1996.

Curson, A. R. J., Todd, J. D., Sullivan, M. J., and Johnston, A. W. B.: Catabolism of dimethylsulphoniopropionate: microorganisms, enzymes and genes, Nature Rev. Microbiol., 9, 849-859, 2011.

del Valle, D. A., Kieber, D. J., Toole, D. A., Bisgrove, J., and Kiene, R. P.: Dissolved DMSO production via biological and photochemical oxidation of dissolved DMS in the Ross Sea, Antarctica, Deep-Sea Res. I, 56, 166-177, 2009.

Engel, A., Zondervan, I., Aerts, K., Beaufort, L., Benthien, A., Chou, L., Delille, B., Gattuso, J.P., Harlay, J., Heemann, C., Hoffmann, L., Jacquet, S., Nejstgaard, J., Pizay, M.D., RochelleNewall, E., Schneider, U., Terbrueggen, A., and Riebesell, U.: Testing the direct effect of $\mathrm{CO}_{2}$ concentration on a bloom of the coccolithophorid Emiliania huxleyi in mesocosm experiments, Limnol. Oceanogr., 50, 493-507, 2005.

Engel, A., Borchard, C., Piontek, J., Schulz, K. G., Riebesell, U., and Bellerby, R.: $\mathrm{CO}_{2}$ increases ${ }^{14} \mathrm{C}$ primary production in an Arctic plankton community, Biogeosciences, 10, 1291-1308, doi:10.5194/bg-10-1291-2013, 2013.

Ferek, R. J., Hobbs, P. V., Radke, L. F., Herring, J. A., Sturges, W. T., and Cota, G. F.: Dimethyl sulfide in the arctic atmosphere, J. Geophys. Res.-Atmos., 100, 26093-26104, 1995.

Franklin, D. J., Steinke, M., Young, J., Probert, I., and Malin, G.: Dimethylsulphoniopropionate (DMSP), DMSP-lyase activity (DLA) and dimethylsulphide (DMS) in 10 species of coccolithophore, Mar. Ecol.-Prog. Ser., 410, 13-23, 2010.

Gabric, A. J., Qu, B., Matrai, P., and Hirst, A. C.: A modelling analysis of the response of dimethylsulphide production in the Arctic Ocean to global warming, Air Pollution XIII, 82, 107-116, 2005.

Gali, M., Salo, V., Almeda, R., Calbet, A., and Simo, R.: Stimulation of gross dimethylsulfide (DMS) production by solar radiation, Geophys. Res. Lett., 38, L15612, doi:10.1029/2011GL048051, 2011.

Held, A., Brooks, I. M., Leck, C., and Tjernström, M.: On the potential contribution of open lead particle emissions to the central Arctic aerosol concentration, Atmos. Chem. Phys., 11, 30933105, doi:10.5194/acp-11-3093-2011, 2011.
Hopkins, F. E., Turner, S. M., Nightingale, P. D., Steinke, M., Bakker, D., and Liss, P. S.: Ocean acidification and marine trace gas emissions, Proc. Natl. Acad. Sci. USA, 107, 760-765, 2010.

Intrieri, J. M., Shupe, M. D., Uttal, T., and McCarty, B. J.: An annual cycle of Arctic cloud characteristics observed by radar and lidar at SHEBA, J. Geophys. Res.-Oc., 107, 8030, doi:10.1029/2000JC000423, 2002.

Johnson, M. T. and Bell, T. G.: Coupling between dimethylsulfide emissions and the ocean-atmosphere exchange of ammonia, Environ. Chem., 5, 259-267, 2008.

Karl, M., Leck, C., Gross, A., and Pirjola, L.: A study of new particle formation in the marine boundary layer over the central Arctic Ocean using a flexible multicomponent aerosol dynamic model, Tellus B, 64, 17158, doi:10.3402/tellusb.v64i0.17158, 2012.

Kay, J. E. and Gettelman, A.: Cloud influence on and response to seasonal Arctic sea ice loss, J. Geophys. Res.-Atmos., 114, D18204, doi:10.1029/2009JD011773, 2009.

Kay, J. E., Holland, M. M., and Jahn, A.: Inter-annual to multidecadal Arctic sea ice extent trends in a warming world, Geophys. Res. Lett., 38, L15708, doi:10.1029/2009JD011773, 2011.

Keller, M. D., Bellows, W. K., and Guillard, R. R. L.: Dimethyl sulfide production in marine phytoplankton, in: Biogenic Sulfur in the Environment., edited by: Saltzman, E. S. and Cooper, W. J., Am. Chem. Soc., 183-200, 1989.

Kiene, R. P. and Slezak, D.: Low dissolved DMSP concentrations in seawater revealed by small-volume gravity filtration and dialysis sampling, Limnol. Oceanogr.-Meth., 4, 80-95, 2006.

Kiene, R. P., Linn, L. J., and Bruton, J. A.: New and important roles for DMSP in marine microbial communities, J. Sea Res., 43, 209-224, 2000.

Kim, J.-M., Lee, K., Yang, E. J., Shin, K., Noh, J. H., Park, K.-t., Hyun, B., Jeong, H.-J., Kim, J.-H., Kim, K.Y., Kim, M., Kim, H.C., Jang, P.-G., and Jang, M.-C.: Enhanced Production of oceanic dimethylsulfide resulting from $\mathrm{CO}_{2}$-induced grazing activity in a high $\mathrm{CO}_{2}$ world, Environ. Sci.Technol., 44, 8140-8143, 2010.

Kloster, S., Six, K. D., Feichter, J., Maier-Reimer, E., Roeckner, E., Wetzel, P., Stier, P., and Esch, M.: Response of dimethylsulfide (DMS) in the ocean and atmosphere to global warming, J. Geophys. Res., 112, G03005, doi:10.1029/2006JG000224, 2007.

Korhonen, H., Carslaw, K. S., Spracklen, D. V., Ridley, D. A., and Strom, J.: A global model study of processes controlling aerosol size distributions in the Arctic spring and summer, J. Geophys. Res.-Atmos., 113, D15204, doi:10.1029/2007JD009114, 2008.

Leck, C. and Persson, C.: The central Arctic Ocean as a source of dimethyl sulfide - Seasonal variability in relation to biological activity, Tellus B, 48, 156-177, 1996.

Lee, P. A., Rudisill, J. R., Neeley, A. R., Maucher, J. M., Hutchins, D. A., Feng, Y. Y., Hare, C. E., Leblanc, K., Rose, J. M., Wilhelm, S. W., Rowe, J. M., and DiTullio, G. R.: Effects of increased $p \mathrm{CO}_{2}$ and temperature on the North Atlantic spring bloom, III. Dimethylsulfoniopropionate, Mar. Ecol.-Prog. Ser., 388, 41-49, 2009.

Mauritsen, T., Sedlar, J., Tjernström, M., Leck, C., Martin, M., Shupe, M., Sjogren, S., Sierau, B., Persson, P. O. G., Brooks, I. M., and Swietlicki, E.: An Arctic CCN-limited cloud-aerosol regime, Atmos. Chem. Phys., 11, 165-173, doi:10.5194/acp-11165-2011, 2011.

Niki, T., Kunugi, M., and Otsuki, A.: DMSP-lyase activity in five marine phytoplankton species: its potential importance in DMS 
production, Mar. Biol., 136, 759-764, 2000.

Nishiguchi, M. K. and Somero, G. N.: Temperature-dependence and concentration-dependence of compatibility of the organic osmolyte beta-dimethylsulfoniopropionate, Cryobiology, 29, 118124, 1992.

Olenina, I., Hajdu, S., Edler, L., Andersson, A., Wasmund, N., Busch, S., Göbel, J., Gromisz, S., Huseby, S., Huttunen, M., Jaanus, A., Kokkonen, P., Ledaine, I., and Niemkiewicz, E.: Biovolumes and size-classes of phytoplankton in the Baltic Sea, HELCOM Baltic Sea Environ. Proc., 106, p. 144, 2006.

Orellana, M. V., Matrai, P. A., Leck, C., Rauschenberg, C. D., Lee, A. M., and Coz, E.: Marine microgels as a source of cloud condensation nuclei in the high Arctic, Proc. Natl. Acad. Sci. USA, 108, 13612-13617, 2011.

Piontek, J., Lunau, M., Händel, N., Borchard, C., Wurst, M., and Engel, A.: Acidification increases microbial polysaccharide degradation in the ocean, Biogeosciences, 7, 1615-1624, doi:10.5194/bg-7-1615-2010, 2010.

Piontek, J., Borchard, C., Sperling, M., Schulz, K. G., Riebesell, U., and Engel, A.: Response of bacterioplankton activity in an Arctic fjord system to elevated $p \mathrm{CO}_{2}$ : results from a mesocosm perturbation study, Biogeosciences, 10, 297-314, doi:10.5194/bg-10297-2013, 2013.

Quinn, P. K., Miller, T. L., Bates, T. S., Ogren, J. A., Andrews, E., and Shaw, G. E.: A 3-year record of simultaneously measured aerosol chemical and optical properties at Barrow, Alaska, J. Geophys. Res.-Atmos., 107, 4130, doi:10.1029/2001JD001248, 2002.

Ragni, M., Airs, R. L., Leonardos, N., and Geider, R. J.: Photoinhibition of PSII in Emiliania huxleyi (Haptophyta) under high light stress: The roles of photoacclimation, photoprotection, and photorepair, J. Phycol., 44, 670-683, 2008.

Raven, J. A.: Half a century of pursuing the pervasive proton, Prog. Botany, 74, 3-36, 2013.

Reed, R. H.: Measurement and osmotic significance of $\beta$-dimethylsulfoniopropionate in marine macroalgae., Mar. Biol., 4, 173$178,1983$.

Reinfelder, J. R.: Carbon concentrating mechanisms in eukaryotic marine phytoplankton, Ann. Rev. Mar. Sci., 3, 291-315, 2011.

Reisch, C. R., Moran, M. A., and Whitman, W. B.: Bacterial catabolism of dimethylsulfoniopropionate (DMSP), Frontiers in Microbiol., 2, 172, 1-12, 2011.

Riebesell, U. and Tortell, P. D.: Effects of ocean acidification on pelagic organisms and ecosystems, in: Ocean Acidification, edited by: Gattuso, J. P. and Hanson, L., Oxford University Press, Oxford, 99-121, 2011.

Riebesell, U., Czerny, J., von Bröckel, K., Boxhammer, T., Büdenbender, K., Deckelnick, M., Fischer, M., Hoffmann, D., Krug, S. A., Lentz, U., Ludwig, A., Muche, R., and Schulz, K. G.: Technical Note: A mobile sea-going mesocosm system - new opportunities for ocean change research, Biogeosciences, in press, 2013.

Rost, B., Richter, K. U., Riebesell, U., and Hansen, P.J.: Inorganic carbon acquisition in red tide dinoflagellates, Plant Cell Environ., 29, 810-822, 2006.

Rost, B., Zondervan, I., and Wolf-Gladrow, D.: Sensitivity of phytoplankton to future changes in ocean carbonate chemistry: current knowledge, contradictions and research directions, Mar. Ecol.Prog. Ser., 373, 227-237, 2008.
Schulz, K. G., Bellerby, R. G. J., Brussaard, C. P. D., Büdenbender, J., Czerny, J., Engel, A., Fischer, M., Koch-Klavsen, S., Krug, S. A., Lischka, S., Ludwig, A., Meyerhöfer, M., Nondal, G., Silyakova, A., Stuhr, A., and Riebesell, U.: Temporal biomass dynamics of an Arctic plankton bloom in response to increasing levels of atmospheric carbon dioxide, Biogeosciences, 10, 161180, doi:10.5194/bg-10-161-2013, 2013.

Sedlar, J., Tjernstrom, M., Mauritsen, T., Shupe, M. D., Brooks, I. M., Persson, P. O. G., Birch, C. E., Leck, C., Sirevaag, A., and Nicolaus, M.: A transitioning Arctic surface energy budget: the impacts of solar zenith angle, surface albedo and cloud radiative forcing, Clim. Dynam., 37, 1643-1660, 2011.

Spielmeyer, A. and Pohnert, G.: Influence of temperature and elevated carbon dioxide on the production of dimethylsulfoniopropionate and glycine betaine by marine phytoplankton, Mar. Environ. Res., 73, 62-69, 2012.

Stefels, J.: Physiological aspects of the production and conversion of DMSP in marine algae and higher plants, J. Sea Res., 43, 183197, 2000.

Stefels, J., Dijkhuizen, L., and Gieskes, W. W. C.: DMSP-lyase activity in a spring phytoplankton bloom off the Dutch coast, related to Phaeocystis sp abundance, Mar. Ecol.-Prog. Ser., 123, 235-243, 1995.

Stefels, J., Steinke, M., Turner, S., Malin, G., and Belviso, S.: Environmental constraints on the production and removal of the climatically active gas dimethylsulphide (DMS) and implications for ecosystem modelling, Biogeochemistry, 83, 245-275, 2007.

Stefels, J., Dacey, J. W. H., and Elzenga, J. T. M.: In vivo DMSPbiosynthesis measurements using stable-isotope incorporation and proton-transfer-reaction mass spectrometry (PTR-MS), Limnol. Oceanogr.-Methods, 7, 595-611, 2009.

Steinacher, M., Joos, F., Frölicher, T. L., Plattner, G.-K., and Doney, S. C.: Imminent ocean acidification in the Arctic projected with the NCAR global coupled carbon cycle-climate model, Biogeosciences, 6, 515-533, doi:10.5194/bg-6-515-2009, 2009.

Steinke, M., Wolfe, G. V., and Kirst, G. O.: Partial characterisation of dimethylsulfoniopropionate (DMSP) lyase isozymes in 6 strains of Emiliania huxleyi, Mar. Ecol.-Prog. Ser., 175, 215-225, 1998.

Steinke, M., Malin, G., Archer, S. D., Burkill, P. H., and Liss, P. S.: DMS production in a coccolithophorid bloom: evidence for the importance of dinoflagellate DMSP lyases, Aqu. Microb. Ecol., 26, 259-270, 2002.

Sunda, W., Kieber, D. J., Kiene, R. P., and Huntsman, S.: An antioxidant function for DMSP and DMS in marine algae, Nature, 418, 317-320, 2002.

Tarran, G. A., Zubkov, M. V., Sleigh, M. A., Burkill, P. H., and Yallop, M.: Microbial community structure and standing stocks in the NE Atlantic in June and July of 1996, Deep-Sea Res. II, 48, 963-985, 2001.

Toumi, R.: BrO as a sink for dimethylsulfide in the marine atmosphere, Geophys. Res. Lett., 21, 117-120, 1994.

Vila-Costa, M., Kiene, R. P., and Simó, R.: Seasonal variability of the dynamics of dimethylated sulfur compounds in a coastal northwest Mediterranean site, Limnol. Oceanogr., 53, 198-211, 2008. 
Vogt, M., Steinke, M., Turner, S., Paulino, A., Meyerhöfer, M., Riebesell, U., LeQuéré, C., and Liss, P.: Dynamics of dimethylsulphoniopropionate and dimethylsulphide under different $\mathrm{CO}_{2}$ concentrations during a mesocosm experiment, Biogeosciences, 5, 407-419, doi:10.5194/bg-5-407-2008, 2008.
Wingenter, O. W., Haase, K. B., Zeigler, M., Blake, D. R., Rowland, F. S., Sive, B. C., Paulino, A., Thyrhaug, R., Larsen, A., Schulz, K. G., Meyerhofer, M. and Riebesell, U.: Unexpected consequences of increasing $\mathrm{CO}_{2}$ and ocean acidity on marine production of DMS and CH2CII: Potential climate impacts, Geophys. Res. Lett., 34, L05710, doi:10.1029/2001JD001248, 2007. 